Isabel Walker Ross

\title{
"Shaping and Cutting and Improving and Adding": \\ Acknowledged and Hidden Influences in Scott Westerfeld's Uglies series and Philip Pullman's His Dark Materials
}

\begin{abstract}
A thesis
submitted to the Victoria University of Wellington in fulfilment of the requirements for the degree of Master of Arts in English Literature
\end{abstract}

School of English, Film, Theatre and Media Studies

Victoria University of Wellington

2010 


\begin{abstract}
This thesis aims to identify and analyse the most prominent influences on Scott Westerfeld's Uglies series and Philip Pullman's His Dark Materials trilogy. It looks particularly at the difference between the authors' attitude towards influences they happily acknowledge and those influences which they attempt to conceal because they cause them anxiety (in the case of Westerfeld) or embarrassment (in the case of Pullman). This focus, combined with the speculative analysis of His Dark Materials' influence on Extras, the fourth book of the Uglies series, is intended to show the variability of literary influence. Comparative close readings throughout the thesis display the variety of ways influences are used within the texts, and illustrate the factors on which their use is dependent: the compatibility of the latecomer text with its precursor, the author's opinion of the earlier work, and the reading the author makes of the precursor text. Pullman's acknowledgement of influences is dependent on whether he considers them worthy precursors (in the case of Heinrich von Kleist, William Blake, and John Milton) or an embarrassing ancestor (in the case of C. S. Lewis). Westerfeld's is dependent on how similar his precursor works are to his own texts, as he does not acknowledge the obvious influence of Aldous Huxley, but happily names Ray Bradbury, John Christopher, Ted Chiang, and Charles Beaumont as influences. The thesis shows that the use of literary influences is not straightforward as one author may, as Westerfeld and Pullman do, display different attitudes to and appropriate precursor texts in differing ways within one work.
\end{abstract}




\section{Acknowledgements}

As Uglies and His Dark Materials would not exist were it not for the influence of prior texts, this thesis would not exist were it not for the support and influence of some people - some obvious, some not. It is only fitting that, like Westerfeld and Pullman, I draw attention to some.

My family. Thank-you for your love and support. Mum and Dad, thank-you for filling our house with books and for raising me to be independent, think for myself, work diligently, and finish what I start - all necessary qualities for writing this thesis.

Harry Ricketts, my supervisor. Thank-you for your advice and encouragement, for reading this thesis countless times as it developed, and for your suggestion early on in the project that a brief overview of influences on Westerfeld might be appropriate and that perhaps I should take a look at Brave New World.

Saskia Voorendt and Lujan Herrera, my officemates. It was great to be around people who understand the ups and downs of the task. Thanks also for the moments of laughter we had amidst the research and writing.

Christine Franzen. Thank-you for your considered reply that yes, I was capable of completing an MA. You probably don't even remember making the comment, and are far too modest to consider it significant, but that affirmation encouraged me to begin.

Many other people have helped me along the way, but I will take my cue from Westerfeld and Pullman and remain silent. Influences, however, can be concealed but not revealed. You know who you are. Thank-you.

Isabel Ross

March 2010 


\section{Table of Contents}

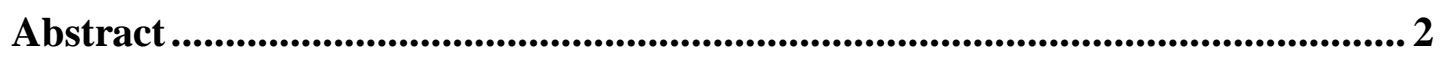





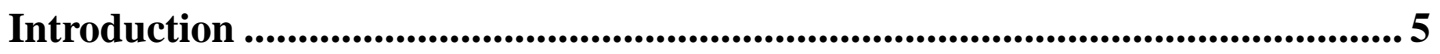

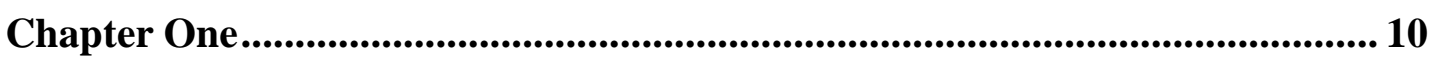

"Everybody Looks the Same": Literary Influences on Scott Westerfeld's Uglies series

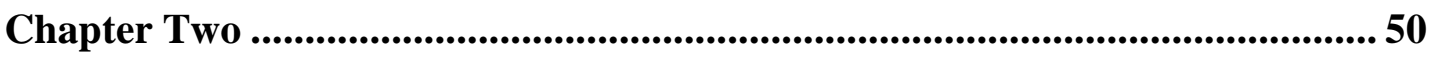

The Nectar Collector: Literary Influences on Philip Pullman's His Dark Materials

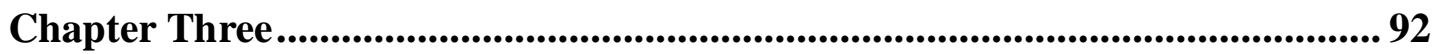

Pullmanian Ideas in Westerfeld's Extras: An Exercise in Hermeneutics

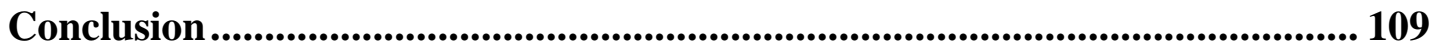

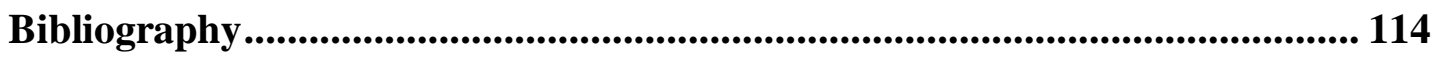




\section{Introduction}

“It's what I've always known. My mother said I'd take up my father's mantle. That's all I know."

"What does that mean, taking up his mantle? What's a mantle?"

“A task, I suppose. Whatever he's been doing, I've got to carry on. It makes as much sense as anything else."1

Pages later, Will literally takes up his late father's mantle as he takes his cloak and wraps it around himself. He feels the heavy burden of completing his father's unfinished work and he knows that his past impacts on his present and future - he cannot forget about it. Conversely Tally is determined to forge a new future for herself which is independent of her past. She is frustrated that she has not been allowed to make her own choices and that she is merely a product of other people's actions - she wants to create her own identity:

Ever since Dr Cable had recruited her, other people had made most of Tally's choices for her ... her only real decisions so far had been staying ugly in the Old Smoke (which hadn't worked out at all), escaping from New Pretty Town with Zane (ditto), and splitting up with Shay to protect Zane (not great so far). Everything else had happened because of threats, accidents, lesions in her brain, and surgery changing her mind for her. ${ }^{2}$

The relationships these two characters have with the past are similar to relationships authors may have with their literary past. In one relationship an author, like Will, realises that they cannot be separated from their past and the influence their precursors have had on their work. Like Will putting on his father's cloak in a visible display of the relationship between the two, they make their influences known by

\footnotetext{
${ }^{1}$ Philip Pullman, The Subtle Knife, (1991; repr., London: Scholastic, 1998), 321. (Hereafter referred to as Knife.)

${ }^{2}$ Scott Westerfeld, Specials, (New York: Simon Pulse, 2006), 184. (Hereafter referred to as Specials.)
} 
acknowledging them. In a relationship akin to Tally's relationship with her past, an author wishes to "create themselves" 3 and not be influenced by prior texts.

Much of the initial research for this thesis looked at the unacknowledged influences on Westerfeld and Pullman and attempted to analyse the purpose of this concealment, expecting it to reveal the authors' attitudes towards influence. However, both unashamedly acknowledge other influences on their work, and it was quickly apparent that the two attitudes to influence are not mutually exclusive as both feature in these authors' novels.

Harold Bloom serves as an ideal champion for the concept of concealed, or unacknowledged, influence. He argues that before the Enlightenment copying was admirable in art and literature. Greatness was attained through "hard work", diligently studying and imitating masters of the craft. The post-Enlightenment passion for genius, however, meant that art became more than "hard work". For a work of art to be great, it had to be unique, employing some new concept or technique which had not been used before. This, claims Bloom, causes great anxiety in the poet (or writer ${ }^{4}$ ) for they desire to be self-begotten but cannot escape the literary tradition of which they are part. The latecomer struggles against the influence of their precursors, and the emergence of a strong poet requires the besting or killing of their literary father. Bloom's theory applies both to the relationship between the Uglies series (2005-2007) and Brave New World (1932) and the relationship between His Dark Materials (1995-2000) and The Chronicles of Narnia (1950-1956). Because strong poets refuse to admit that they have failed to create

\footnotetext{
${ }^{3}$ Harold Bloom, The Anxiety of Influence: A Theory of Poetry, $2^{\text {nd }}$ Ed. (New York: Oxford University Press, 1997), 5. (Hereafter referred to as Anxiety.)

${ }^{4}$ Anxiety, 27. Bloom refers to poets throughout Anxiety, but his theory can equally apply to the more generic category of "writers", as it will throughout this thesis. T. S. Eliot also refers to "poets", and his use of the term is also interchangeable with "writer".
} 
themselves, Bloom contends, they experience "immense anxieties of indebtedness.", Westerfeld's relationship with Huxley reflects this, as he appears to be worried that he has taken so much from Brave New World that his series may seem a weak copy of its precursor. Bloom's Paradise Lost analogy can be applied to Pullman's relationship with Lewis. Bloom compares Satan to the modern poet, and God to the dead - but embarrassingly potent and present - ancestor. ${ }^{6}$ Pullman, like Satan, wants to usurp his "ancestor". He does not want his work to resemble Lewis's, but wants to surpass it. However, he cannot surpass Lewis's work without it being obvious that this is what he is aiming to do, which in itself affirms that work as an influence.

T. S. Eliot famously observed that "immature poets imitate; mature poets steal" and the full quotation further explains this idea:

One of the surest of tests is the way in which a poet borrows. Immature poets imitate; mature poets steal; bad poets deface what they take, and good poets make it into something better, or at least something different. The good poet welds his theft into a whole of feeling which is unique, utterly different from that which it was torn ...

Eliot suggests that poets should embrace the unavoidable influence of the literary past. The comparison with their precursors is inevitable and they ought to be aware of this. Eliot insists that a poet should continue to develop their knowledge of the past, and that being subject to influence does not lessen a work's individuality. In fact, "the most individual parts of [a poet's] work may be those in which the dead poets, his ancestors, assert their immortality most vigorously." 8 A great writer is capable of transforming his influences into something new, so he should not be ashamed of these influences. David Cowart (writing after Eliot) claims that literary

\footnotetext{
${ }^{5}$ Anxiety, 5.

${ }^{6}$ Anxiety, 20.

7 T. S. Eliot, "Philip Massinger", 1920. In Selected Essays, 205-220, (London: Faber and Faber, 1951), 206.

${ }^{8}$ T. S. Eliot, "Tradition and the Individual Talent", 1919. In Selected Essays, 13-22, (London: Faber and Faber, 1951), 14.
} 
symbiosis, the most straightforward manifestation of influence, "counters the occasional notion in popular criticism that literary indebtedness is some kind of embarrassment to artists, something they do not want recognized." ${ }^{\text {"9 }}$ Symbiosis is admittedly an extreme form of influence, but it illustrates how an author may choose blatantly to highlight their precursors. His Dark Materials could be considered a symbiont of Paradise Lost in the same way that Cowart considers Paradise Lost to be a symbiont of Genesis, ${ }^{10}$ each text reinterpreting the precursor work for a new age. It would be impossible for Pullman to deny the influence of Milton's epic as it is so present in his own work, suggesting that he is unashamed of it. Likewise, Westerfeld is unashamed of influences on the Uglies series - apart from that of Brave New World.

The overarching aim of this thesis is to explore literary influence as it functions in the Uglies series and His Dark Materials, and examine how far Westerfeld and Pullman are willing or unwilling to acknowledge different influences. The thesis consists largely of comparative close readings of influenced and influencer texts, which positions it then to look at the wider impact the precursor texts have on the latecomer texts.

Chapters One and Two will examine the literary influences on Uglies and His Dark Materials respectively. Each chapter will first explore those influences which are acknowledged, identifying how Westerfeld and Pullman use these precursor texts and evaluating the impact this has on their own series. The unacknowledged influences which nevertheless permeate the texts will then be looked at. As with the acknowledged influences, the way in which these hidden influences are used will be identified, and the impact they have upon Westerfeld's and Pullman's series

\footnotetext{
${ }^{9}$ David Cowart, Literary Symbiosis: The Reconfigured Text in Twentieth-Century Writing, (Athens, Ga: University of Georgia Press, 1993), 2. (Hereafter referred to as Symbiosis.)

${ }^{10}$ Symbiosis, 10.
} 
evaluated. Chapter Three will consider a third type of influence - indirect influence. It will look at an apparent Pullmanian influence on Westerfeld which is itself influenced by critical writings on His Dark Materials in the form of an anthology of essays which Westerfeld edited. ${ }^{11}$

As Lyra, in The Amber Spyglass, tells a story "shaping and cutting and improving and adding [to]"12 an earlier tale, in their stories Westerfeld and Pullman shape, cut, and add to their precursor texts. The key finding of this research is that influence is not straightforward, and that two opposing attitudes to influence (concealing or revealing it) can be found in one literary work. Many different uses of influences were found in the works of Westerfeld and Pullman, illustrating how a writer's attitude to and use of different influences can vary widely.

\footnotetext{
${ }^{11}$ Scott Westerfeld, ed. The World of the Golden Compass: The Otherworldly Ride Continues, (USA: BenBella Books, 2009.) (Hereafter referred to as World.)

${ }^{12}$ Philip Pullman, The Amber Spyglass, (2000; repr., London: Scholastic, 2001), 307. (Hereafter referred to as Spyglass.)
} 


\section{Chapter One}

\section{"Everybody Looks the Same": Literary Influences on Scott Westerfeld's Uglies series}

Scott Westerfeld openly acknowledges four significant influences on the Uglies series. He states on his Amazon website profile that "I always think my influences are pretty obvious, but here are some clues: Uglies comes from John Christopher's Tripods series and Ray Bradbury's Fahrenheit 451." ${ }^{\prime 3}$ Two short stories, Ted Chiang's "Liking What You See: A Documentary” (2002) and Charles Beaumont's “The Beautiful People" (1952) are included in Mind-Rain (2009, a collection of essays about the Uglies series, edited by Westerfeld) as they "inspired [him] to invent Tally's world."14 "Liking What You See" is even acknowledged in Uglies, where Westerfeld writes:

This novel was shaped by a series of e-mail exchanges between myself and Ted Chiang about his story "Liking What You See: A Documentary." His input on the manuscript was also invaluable. ${ }^{15}$

Westerfeld uses these texts in an imitative manner, often creatively so. Interestingly, he does not mention a seemingly greater influence: that of Aldous Huxley's Brave New World (1932), which he could be said to have refunctioned for a new audience. Each of these five texts explores the issue of socialisation, and much of what Westerfeld appropriates from them relates to this theme. Lesions and the Operation, means of social control in Westerfeld's work, are adapted from Caps (Tripods), calliagnosia ("Liking What You See"), and book-burning (Fahrenheit 451). In a less aggressive social engineering tactic than lesions, the authorities in Uglies prey upon

\footnotetext{
${ }^{13}$ Scott Westerfeld, "Profile Page", Amazon. http://www.amazon.com/gp/pdp/profile/AIUSWOSM0 W9NB. (accessed July 20, 2009).

${ }^{14}$ Scott Westerfeld, ed. Mind Rain, (Dallas: BenBella Books, 2009), 3. (Hereafter referred to as MindRain.)

${ }^{15}$ Scott Westerfeld, Uglies, (New York: Simon Pulse, 2005), copyright page. (Hereafter referred to as Uglies.)
} 
people's desire to be attractive, expecting them to comply with society in order to be made pretty. Similar approaches are used in Westerfeld's precursor works where the societies constructed compel citizens to maintain the status quo.

A blog entry, "First Lines", posted by Westerfeld on his website encapsulates his attitude toward influence:

There is a mini-cult of first lines among us writers. The first line is sort of like the lobby of the book: the first thing you see, coloring all subsequent impressions. It's one place where you're truly allowed to show off ... As many people have spotted, Uglies, which begins:

The early summer sky was the color of cat vomit.

pays homage to the opening of William Gibson's Necromancer:

The sky above the port was the color of television, turned to a dead channel. ${ }^{16}$

Two attitudes are displayed in this statement. First, that Westerfeld's work "pays homage" to Gibson's suggests that he considers literary influence to be a normal, even admirable, characteristic of a text. Second, Westerfeld wants to demonstrate his own cleverness. He states "you're truly allowed to show off", and the following comparison of the two novels' opening lines suggests that this is exactly what he is doing here. ${ }^{17}$ These attitudes are further seen in the way he uses his literary influences. Uglies pays homage to "The Beautiful People" and the Tripods series (1967-1968), as Westerfeld employs them in a largely imitative manner. His use of "Liking What You See" and Fahrenheit 451 (1953) is similarly imitative but with a greater level of adaptation - and he wants people to recognise this. Westerfeld's imitation of Beaumont's and Bradbury's texts can be considered a pastiche as it imitates characteristic aspects of the prior works so that their influence is obvious.

\footnotetext{
${ }^{16}$ Scott Westerfeld, "First Lines", 26 July 2008. http://www.scottwesterfeld.com/blog/?p=507. (accessed December 4, 2009).

${ }^{17}$ This type of allusive play is typical of Westerfeld, as it occurs elsewhere in his work. For example, the last word of Uglies is "pretty", and the last word of Pretties is "special", and the last word of Specials is "ugly". Westerfeld directs readers to this, explaining it in Bogus to Bubbly: An Insider's Guide to the World of Uglies, (New York: Simon Pulse, 2008. Hereafter referred to as Bogus) before adding: "There's no point in us writers putting stuff like that in if you don't notice!" (p.167-168.)
} 
His use of these novels shows that he has read and understood them (and presumably enjoyed them enough to pay homage to them), but he is not as creative with them as he is with other works. From Beaumont, he borrows the setting of the story. "The Beautiful People" is set in a world where, aged nineteen, people undergo a Transformation which makes them beautiful, resulting in a society of people who all look alike. The protagonist Mary, like Tally, is opposed to the procedure. In acknowledging the Tripods series as an influence, Westerfeld draws attention to the connection between the Operation and Capping, as both are tactics the authorities use to control people.

Westerfeld also explicitly adapts aspects of Chiang's and Bradbury's texts. "Liking What You See", he remarks, describes an approach to beauty which is "the exact opposite of the Pretty system." ${ }^{18}$ He has inverted the system in his own work. If the system in Chiang's work was enforced, everyone would have an operation which, rather than changing their appearance, would change the way they see. Subjects are therefore unable to distinguish between attractive and unattractive people. The operations in each text are intended to make everyone equal. Though the processes are in themselves opposite, the results are the same, and there are both similarities and differences between the texts.

Amanda Craig, writing for Times Online, explains (having interviewed Westerfeld) that "He sees [the] literal loss of face [in Uglies] as a loss of culture, akin to the books destroyed in Ray Bradbury's Fahrenheit 451."19 During the Operation in Uglies, surgeons "grind and stretch your bones to the right shape, peel off your face and rub all your skin away, and stick in plastic cheekbones so you look

\footnotetext{
${ }^{18}$ Mind-Rain, 155.

${ }^{19}$ Amanda Craig, "The Future Imperfect", Times Online November 2006, http://entertainment.timeso nline.co.uk/tol/arts_and_entertainment/books/children/article1087018.ece. (accessed May 25, 2009). (Hereafter referred to as "Imperfect".)
} 
like everybody else" ${ }^{20}$ An individual literally loses their face - their bone structure is changed, the skin removed and replaced - and the result is that everyone looks the same. This parallels Fahrenheit 451 where the burning of books means that the culture they possess is lost and a similar monoculture is cultivated - the people in Bradbury's world are all shallow and "each man the image of every other". ${ }^{21}$

While there are strong parallels between Huxley's Brave New World and the Uglies series, Westerfeld does not acknowledge it as an influence. Though he is silent about this connection, it has been noticed by others. Amanda Craig claims that "The American author has written what amounts to a Brave New World for our time". ${ }^{22}$ Similarly, journalist Cecilia Goodnow has commented that "Collectively, the quartet is a sort of Brave New World for teens". ${ }^{23}$ Certainly there are thematic links between the works, and the likeness between them is highlighted by Westerfeld's inclusion of a reservation in Pretties (2005), and the character of Andrew Simpson Smith. These elements both find a precedent in Huxley's work: the Reservation, and the character of John Savage.

Why does Westerfeld not acknowledge Huxley's novel as an influence, when he is so blatant in his acknowledgement of other works? The key to this lies perhaps in exactly how similar the works are. Mimicry is generally not a desired quality in literature. Despite T. S. Eliot's famous claim that “immature poets imitate; mature poets steal", ${ }^{24}$ any writer stealing another writer's work is accused of plagiarism, and the line between imitation and stealing is a fine one.

\footnotetext{
${ }^{20}$ Uglies, 50.

${ }^{21}$ Ray Bradbury, Fahrenheit 451, (1953; repr., London: Corgi Books, 1967), 62. (Hereafter referred to as Fahrenheit.)

22 "Imperfect".

${ }^{23}$ Cecilia Goodnow, "Young Adults See Reality Creeping Into Author's World of Faux Beauty", Seattle Pi October 18 2007, www.seattlepi.com/lifestyle/336024_uglies19.html. (accessed 1 July 2009).

${ }^{24}$ T. S. Eliot, "Philip Massinger", 1920. In Selected Essays, 205-220, (London: Faber and Faber, 1951), 206.
} 
Harold Bloom argues that all new poems are influenced by earlier ones, and that this causes anxiety in the poet, for they worry that their work is nothing more than a weak imitation. This may be how Westerfeld feels towards Brave New World. According to Bloom, strong poets manage to overcome their anxiety and misread the original text in some way, so that their text "is an instance of creative revisionism." 25 He likens these "strong poets" to Oedipus, observing:

Oedipus, blind, was on the path to oracular godhood, and the strong poets have followed him by transforming their blindness toward their precursors into the revisionary insights of their own work. $^{26}$

Writers, then, turn a blind eye toward aspects of their precursors' work, so that while their writing is influenced by prior texts, their new interpretation is also present.

The "revisionary insights" to which Bloom refers are, as they appear in Uglies, a result of Westerfeld's refunctioning of Brave New World. "Refunctioning" is a translation of the German term "umfunktionierung" used by Bertolt Brecht to describe the structural reorganisation of stage-author-audience relationships in theatre. ${ }^{27}$ It has been incorporated into critical discourse, though it must be noted that the term is interpreted and applied in different ways by different critics. Terry Eagleton defines it as "a deliberate using or appropriation of an artefact" 28 in order to give it a new or contemporary meaning. Margaret A. Rose asserts that Brecht considered the production of literature as intending to meet certain social needs, and it therefore could be refunctioned for new purposes or new audiences. ${ }^{29}$ This matches Uglies' relationship to Brave New World: the refunctioning of the prior text

\footnotetext{
${ }^{25}$ Anxiety, 42.

${ }^{26}$ Anxiety, 10.

${ }^{27}$ Peter Thomson and Glendyr Sacks, eds, The Cambridge Companion to Brecht, (Cambridge: Cambridge University Press, 1994), 81.

${ }^{28}$ Terry Eagleton, "Refunctioning". In The Routledge Dictionary of Literary Terms, edited by Peter Childs and Roger Fowler, 201-202, (London: Routledge, 2006), 202.

${ }^{29}$ Rose, Margaret A. Parody//Meta-fiction: An Analysis of Parody as a Critical Mirror to the Writing and Reception of Fiction, London: Routledge and Kegan Paul, 1973, 36.
} 
for - as Amanda Craig suggests - a Young Adult audience. Westerfeld adopts aspects of the prior work, but transforms them so that they have a new meaning for his teenage readership. One instance is the way he uses beauty as a theme. It is a minor theme in Brave New World, and is treated similarly in the Uglies series but is much more prominent there - as this is a large concern among the teenage audience Westerfeld writes for, but not for the adult audience that Brave New World addresses.

Introducing Beaumont's story in Mind-Rain, Westerfeld claims that "Uglies fans will certainly recognize its fundamental setting - a society in which conformity begins with a perfect face." ${ }^{30}$ Direct correlations can be drawn between the texts the characters Shala and Shay are comparable, as is the treatment of sleep and dreams. Societal setup, and the related issues of conformity and beauty, are similarly portrayed in the two works.

Shay's and Shala's names look and sound similar, and Tally's nickname for Shay, "Shay-la", is even closer. Both characters have the Operation or Transformation before Tally and Mary. In a slight deviation from - or inversion of the original text, in Uglies it is Shay who does not want to have the Operation, but in “The Beautiful People" Shala does want the Transformation.

Sleep is also similar in each work. In Mary's world people do not sleep, and she is chastised by the doctor because she has:

${ }^{30}$ Mind Rain, 133. 
“Mary, don't you know nobody sleeps anymore. That we have an infinitely greater life-span than our poor ancestors now that that wasteful state of unconsciousness has been conquered? Child, have you actually slept? No one knows how anymore., ${ }^{31}$

Specials have been designed to sleep in ten minute intervals, wake up, and then sleep again. They have not yet conquered the "wasteful state of unconsciousness", but work to minimise it, so that they remain alert to their surroundings. Sleep is detrimental in each instance - a waste of time that prevents activity. Mary manages to fall asleep, "softly and without realizing it. But the sleep was not a peaceful one." ${ }^{32}$ The story concludes ominously, as a dream sequence in which Mary is forced to have the Transformation. Pretties concludes similarly with an unpleasant dream sequence in which Tally is turned into a Special.

Perfection is important in the worlds that each text describes. Mary in "The Beautiful People" glances through a magazine, looking at "Women and men, all looking alike, all perfect and beautiful." ${ }^{33}$ Were she a character in Uglies, one would imagine that any magazine she read would be similar. In each depicted world, people look alike because perfection is created from a limited range of characteristics. Mary later notes how "the halves of [her mother's] face corresponded precisely." ${ }^{34}$ This is also an aspect of the science behind the Operation in Uglies. Known as the "symmetry hypothesis", this theory suggests that people find a symmetrical face more attractive than an asymmetrical one. ${ }^{35}$ Shay and Tally, making "morphos", begin by making their images symmetrical:

\footnotetext{
${ }^{31}$ Charles Beaumont, "The Beautiful People", 1952. In Mind Rain, edited by Scott Westerfeld, 133154, (Dallas: BenBella Books, 2009), 139. (Hereafter referred to as "Beautiful".)

32 "Beautiful", 148.

33 "Beautiful", 135.

34 "Beautiful", 141.

${ }^{35}$ Bogus, 88.
} 
Ugly faces were always asymmetrical; neither half looked exactly like the other. So the first thing the morpho software did was take each side of your face and double it, like holding a mirror right down the middle, creating two examples of perfect symmetry. ${ }^{36}$

The idea that to be beautiful one must be perfectly proportioned is present in each work. And in each world, those who are not perfect are insignificant. Mary, in a dream, looks at a group of people and notices that everyone is perfect, "Except the young ones, young like herself, seated on couches, looking embarrassed and ashamed and eager. But, of course, the young ones did not count." ${ }^{37}$ Likewise, uglies "do not count". This is shown in the lack of interaction between uglies and new pretties, and by Tally's realisation that "of course, [she] was nothing here" 38 when she visits New Pretty Town as an ugly. Those who have had the Transformation or Operation have greater social standing than those who have not.

The two processes of becoming beautiful are similar. The Transformation takes place when the subject is nineteen and their body is developed enough to handle the process. The Operation takes place when the subject is sixteen and their bone structure has set enough for it. Everyone is expected to want to undergo these processes, and Mary and Shay are greeted with shock when they do not. A doctor examining Mary says to her, "that's impossible. I have never heard of such a thing. Little girl, you are playing a joke", ${ }^{39}$ and becomes so distressed that he requests Mary and her mother change doctors. Tally thinks Shay is joking when she says she does not want to become pretty. When Shay reveals her plan to run away and avoid the Operation, Tally replies: "Not be pretty? That's crazy, Shay. All the times you talked that way, I thought you were just being stupid." ${ }^{40}$ Unlike the doctor, however,

\footnotetext{
${ }^{36}$ Uglies, 42.

37 "Beautiful", 151.

${ }^{38}$ Uglies, 7.

39 "Beautiful", 138.

${ }^{40}$ Uglies, 90.
} 
she does not cut all ties with Shay and is excited to be reunited with her at the Smoke.

During Mary's dream, a petition is put forward urging that she "shall, upon final refusal, be forced by law to accept the Transformation. And that an act of legislature shall make this universal and binding in the future." ${ }^{41}$ In Tally's city the Operation is compulsory. People must run away from the city to avoid it, and Special Circumstances enforce it on those who do not want it. The Smokies believe that, having been captured by the Specials, they will be returned to the city and turned pretty - which is what happens to Shay.

This similarity is indicative of the significance of Beaumont's influence on Westerfeld. Beaumont's story ends before the reader discovers Mary's fate, though her dream suggests that she will have the Transformation. The same uncertainty is not present in Uglies where Tally does have the Operation. Westerfeld suggests that he wanted his series to answer the question posed by a Twilight Zone episode based on Beaumont's story: “Given the chance, what young girl wouldn't happily exchange a plain face for a lovely one? What girl could refuse the opportunity to be beautiful?"42 Uglies responds to this issue as Westerfeld extends the world established in "The Beautiful People" and explores the character of Tally, a girl who refuses the opportunity to be pretty. Though his appropriation of the precursor text is straightforward borrowing, Westerfeld transcends this influence in the sense that his story is a continuation of Beaumont's, built on the foundation established by the precursor text.

\footnotetext{
41 "Beautiful", 149.

42 “Number 12 Looks Just Like You”, 1964, quoted in Mind-Rain, 133.
} 
There are a number of direct individual parallels between Westerfeld's Uglies series and Christopher's Tripods series. Will's journey in The White Mountains (1967), following a map, is mirrored by Tally's journey in Uglies to the Smoke, following Shay's instructions. Will unwittingly gets capping metal on his skin in The White Mountains, while in Pretties Zane unwittingly has a tracking device implanted in his tooth. The selection of three candidates for the Games in The City of Gold and Lead (1967) is similar to the selection of those to become Specials - both are decisions based on talent and ability. Will is taken to the masters' city in The City of Gold and Lead where he discovers pyramids. In one of them are rows of caskets with beautiful dead girls inside, for the masters to admire - the theme of admiration of beauty is an important part of Uglies. The Tripods can communicate with each other, and the city, by invisible rays, and the Specials can communicate with each other by skintennas. At the conclusion of the Tripods series, hot air balloons are used to attack the masters' city, and in Pretties hot air balloons are used to escape New Pretty Town.

A more significant parallel between the series is that of Capping and the Operation, which are similar in their function, result, purpose, and justification. As they occur during adolescence, both mark a person's coming of age. In The City of Gold and Lead the reader learns that "Capping took place in one's fourteenth year, marking the change from child to adult." ${ }^{, 43}$ When Will's friend Jack is capped in The White Mountains, it is remarked that it has made him a man, and he will now do a man's work and receive a man's pay. ${ }^{44}$ The Operation takes place at sixteen, and marks the moving into the next stage of life as the person changes from an ugly to a

\footnotetext{
${ }^{43}$ John Christopher, The City of Gold and Lead, (1967; repr., New York: Aladdin Paperbacks, 1988), 3. (Hereafter referred to as City.)

${ }^{44}$ John Christopher, The White Mountains, (1967; repr., Middlesex: Kestrel Books, 1984), 20-21.

(Hereafter referred to as Mountains.)
} 
new pretty, and moves into New Pretty Town. In both instances, these events mark one's transition into a new life - and in each instance, the person appears to become a new person. When someone undergoes the Operation, the reader is told that "they rubbed you raw, and you grew all new skin, perfect and clear. The old marks of accidents and bad food and childhood illnesses all washed away." ${ }^{45}$ The Operation literally makes someone a new person. This is evident when Tally sees Peris for the first time after his transformation. She asks hopefully if they are still best friends, but he is dismissive:

Peris sighed. He wasn't looking at her hand, or into her eyes. Not into her squinty, narrowset, indifferently brown eyes. Nobody eyes. "Yeah," he said. "But, I mean - couldn't you have waited, Squint?"46

He states further, "I'm so different now" and tells her "you're such a kid still.",47 Tally again asks if they are best friends, and he sighs and tells her, "sure, forever. In three months." ${ }^{48}$ Will has similar encounters with Jack after he has been capped:

From time to time I met Jack, and we exchanged words that meant nothing. His manner to me was amiable and distant: it carried the hint of a friendship suspended, a suggestion that he was waiting on the far side of a gulf which in due course I would cross, and that then everything would be as it had before. This did not comfort me, though, for the person I missed was the old Jack, and he was gone forever. ${ }^{49}$

In each instance, the pair are no longer friends - the Peris and Jack Tally and Will knew no longer exist. Conversation between them is distant, as if the Capping and the Operation have made them strangers - they are no longer equal, and their friendships have been lost.

\footnotetext{
${ }^{45}$ Uglies, 25.

${ }^{46}$ Uglies, 17.

${ }^{47}$ Uglies, 18.

${ }^{48}$ Uglies, 20.

${ }^{49}$ Mountains, 23.
} 
Happiness and satisfaction are the results of both Capping and the Operation. Will summarises the Capping, saying that "now all men are happy, having the Masters to rule and help them, and there are no more wars and wickedness." ${ }^{50} \mathrm{He}$ also remarks that:

Before Capping there might be doubts and uncertainties and revulsion ... when the Cap was put on, the doubts vanished. How great a loss was that? Was it a loss at all? The Tripods, apart from the act of Capping itself, did not seem to interfere much with men. ${ }^{51}$

This has its counterpart in Uglies: Pretties are happy to be pretty, and there is (in theory) no fighting between them. Shay, like some before Capping, did not want to have the Operation. But as a pretty she is satisfied:

"I like the way I look," Shay insisted. "I'm happier in this body. You want to talk about brain damage? Look at you all, running around these ruins playing commando. You're all full of schemes and rebellions, crazy with fear and paranoia, even jealousy... That's what being ugly does. ${ }^{52}$

The question posed by Will - "How great a loss was that?" - could be asked of the Operation. How great a loss is it for pretties to lose their anxiety about becoming so? Will implies that it is significant that the Tripods do not often interfere with people, and the same can be said of Special Circumstances: "To most people they were just rumors and urban legends, blamed whenever anything weird happened. Specials kept themselves well hidden." 53

As metaphors for socialisation, Capping and the Operation enable the authorities to control minds. Caps "keep men docile and obedient to [the tripods]", and "control the brain. How, or to what extent, we are not sure ... certain general orders are given when the Cap is put on. Later, specific orders can be given to

\footnotetext{
${ }^{50}$ City, 154.

${ }^{51}$ Mountains, 100-101.

${ }^{52}$ Uglies, 408.

${ }^{53}$ Scott Westerfeld, Pretties, (New York: Simon Pulse, 2005), 19-20. (Hereafter referred to as Pretties.)
} 
specific people". ${ }^{54}$ Lesions, a mass of cells in the brain which are created during the Operation, condition Westerfeld's pretties to think in a certain way - a way compliant with the authorities' regime. As processes, Capping and the Operation are similar - both require surgery or a procedure which modifies the brain, and allow the subject to be controlled. However, the Caps allow for orders to be given, while the Operation creates a mindset that ensures people think and act in a socially acceptable way - but the authorities cannot give direct orders through the lesions. Different mechanisms are used to create the same result.

In both cases, the processes make the controlled unable to fight the controllers. Beanpole asks Hans if the Caps prevent those wearing them from wanting to fight against the Tripods. He gets no reply - only that wanting to fight them would not make sense. ${ }^{55}$ David, in Uglies (2005), responds to the question "why are there no wars?" with the observation that "there are no more controversies, no disagreements, no people demanding change. Just masses of smiling pretties, and a few people left to run things." ${ }^{, 56}$ It is certainly the case in Uglies that the Operation prevents anyone from wanting to fight against the authorities.

Similar justifications are given for Capping and the Operation. Ruki, a captured master, claims that Capping results in less disease and starvation, that Capped people enjoy their lives and are happy, and that it has meant "An end had been made to that hideous state of affairs in which men could be taken from their homes and sent to far lands, there to kill or be killed by strangers with whom they had no direct or personal quarrel." ${ }^{, 57}$ These three aspects form part of the justification for the Operation. There is less starvation because the population is controlled, with

\footnotetext{
${ }^{54}$ Mountains, 33.

${ }^{55}$ City, 67.

${ }^{56}$ Uglies, 267.

${ }^{57}$ John Christopher, The Pool of Fire, (1968; repr., Middlesex: Kestrel Books, 1984), 61.
} 
people encouraged to have only one child every few decades. ${ }^{58}$ There is no war, as those with the lesions are impossible to make into soldiers. ${ }^{59}$ Pretties, like the Capped, enjoy their lives and are happy.

A further parallel is the preservation and bias of history, a theme which develops throughout each series. The masters in The City of Gold and Lead preserve aspects of Earth as it was before they came, keeping extinct animals and flowers on display. History is also preserved in Uglies. School trips are taken to the Rusty Ruins, "the remains of an old city, a hulking reminder of back when there'd been way too many people, and everything was incredibly stupid", ${ }^{60}$ so that students can learn what life on Earth used to be like, and understand the superiority of their own world.

In each series a biased view of history is taught. Fritz says to Will that the Tripods "had the Capped destroy all the books that held the knowledge of the ancients". ${ }^{61}$ The implication is that the subservient are taught a particular view of history, so that they are unaware of problems in their present society. Uglies learn a subjective view of history at school, and they do not see much outside the city. When she is outside, Tally marvels that the city is small. Shay tells her "That's what you can never tell from inside ... How small the city is. How small they have to make everyone to keep them trapped there." ${ }^{2}$ To make everything "small", the authorities have to ensure that people learn only what they want them to believe. When David tells Tally about the specific causes of the oil plague that nearly destroyed Earth's civilisation, she remarks:

\footnotetext{
${ }^{58}$ Bogus, 35.

${ }^{59}$ Bogus, 35.

${ }^{60}$ Uglies, 48.

${ }^{61}$ City, 147.

${ }^{62}$ Uglies, 208.
} 
"It's funny. At school, they never talk much about how it happened - the last panic, when the Rusty world fell apart. They shrug and say that all their mistakes just kept adding up, until it all collapsed like a house of cards ... I wonder why they didn't tell us that in history class. They usually love any story that makes the Rusties sound pathetic."63

To which David replies, "Maybe they didn't want you to realize that every civilization has its weakness. There's always one thing we depend on. And if someone takes it away, all that's left is some story in a history class." ${ }^{64}$ In both texts the presentation of history is a social engineering tactic. The authorities have an agenda in the warped version of history they present - to maintain the stability of society, and the faith people have in the society and its authorities.

Like his use of "The Beautiful People", Westerfeld's use of Christopher's series is mimetic. Westerfeld borrows specific details from Tripods which appear in his story as minor, isolated parallels. These instances are insignificant in the wider scheme of the text. He slightly adapts Capping and the preservation of history to use in his own work, but this adaptation is done to ensure the elements are compatible with the rest of the Uglies series. Wearing a metal cap, for instance, would not be considered "pretty-making" by the characters in Uglies, but implanting lesions in people's brains has no effect on their appearance. Westerfeld's adaptation of the Tripods series does not create a different meaning - the underlying theme remains the same, the dangers of extreme social control.

Westerfeld credits Ted Chiang's short story "Liking What You See: A Documentary" as "the story that started it all." ${ }^{, 65}$ He considers the approach to beauty

${ }^{63}$ Uglies, 344-346.

${ }^{64}$ Uglies, 346.

${ }^{65}$ Mind-Rain, 155. 
in this story as directly opposite to the "pretty system" in the Uglies series. ${ }^{66}$ Rather than change the way people look and think, calliagnosia in Chiang's story changes the way people see, as they are left unable to tell beautiful faces from ordinary faces. The result of each process however is the same: equality. As the operations are both similar and opposite, so are the texts.

Tamera Lyons goes to a school where calliagnosia is compulsory, and she looks forward to having it switched off when she turns eighteen. This is similar to uglies having the Operation at sixteen, but also a point of opposites. Tamera will effectively have the operation reversed at this age, but Tally and others in her world have their Operation at sixteen. Tamera's father says that "eighteen's the age of legal majority, when everyone's got the right to make their own decisions", 67 and that he feels it is right for Tamera to choose whether she has her calliagnosia switched off or not. Ironically, in the Uglies series sixteen is the age at which everyone loses the ability to make their own decisions, as the lesions rewire people's brains so that they think and act according to the authorities' wishes.

Being pretty plays a part in both texts. Tamera's mother Rachel says that "some girls get the message that they can get through life relying on just their looks, and then they never develop their minds", and that "Being pretty is fundamentally a passive quality; even when you work at it, you're working at being passive." ${ }^{\circ}$ Westerfeld's pretties are similar, unable to develop their minds due to the lesions. Some characters in Chiang's work present calliagnosia as good because it prevents the abundance of pretty girls who do not use their minds. In Westerfeld's work, the authorities consider an abundance of pretties a good thing, because they cannot

\footnotetext{
${ }^{66}$ Mind-Rain, 155.

${ }^{67}$ Ted Chiang, "Liking What You See: A Documentary", 2002. In Mind Rain, edited by Scott Westerfeld, 155-196, (Dallas: BenBella Books, 2009), 162. (Hereafter referred to as "Liking".)

68 “Liking”, 161.
} 
threaten the stability of society. In regard to being pretty, it is worth noting that Tamera "becomes" pretty, in the sense that she had not realised that she was attractive before having her calliagnosia switched off. This is mirrored in Westerfeld's series as people literally become pretty due to the Operation.

A vital aspect of the Uglies series, lesions, are mentioned in "Liking What You See". A neurologist acknowledges that study of the brain was traditionally done by observing flaws resulting from naturally occurring lesions. Neurostat - a programmable pharmaceutical - acts as a manufactured lesion, and can be stimulated in the smallest portion of the brain. This is what calliagnosia is. Westerfeld inverts this definition of lesions in his work, as his lesions are unnatural and act in the same way as Chiang's neurostat.

The justifications given for each operation are similar. Student Maria deSouza believes that calliagnosia should be compulsory at Pembleton University because it makes everybody equal. Citing the societal problem of "lookism", she says that prejudice against unattractive people would be eradicated by universal calliagnosia. A similar argument forms part of the justification presented for the Operation in Uglies. Uglies learn in school that before the Prettytime "Everyone judged everyone else based on their appearance. People who were taller got better jobs, and people even voted for some politicians just because they weren't quite as ugly as everybody else. ${ }^{\prime 69}$ In each text the claim is that the operation creates equality within society.

Control is a theme in "Liking What You See" and is picked up in Uglies. In Chiang's story, neurostat treatments (of which calliagnosia is one) cannot control the

${ }^{69}$ Uglies, 44. 
brain to any great extent, but merely "shape broad aspects of personality". 70 Education must be relied upon for specific conditioning. In this scenario, education plays a major part and medicine a minor part in the shaping of a person's personality. The reverse is true in Uglies. Lesions control the brain to a much greater extent, and education plays a secondary, supportive role in conditioning. Education presents the Operation positively and aims to make people want to be pretties, but it is not foolproof. Shay's initial resistance to and her disbelief in what she has been taught demonstrates this. Medicine, however, succeeds where education has failed. Shay is forced to have the Operation, and lesions are created in her brain. She has then been re-formed into the required mould.

The controlling of people in each text raises ethical questions. A student remarks in "Liking What You See" that "Anyone who says the calli movement is good for women is spreading the propaganda of all oppressors: the claim that subjugation is actually protection." ${ }^{, 71}$ It is suggested that those with calliagnosia would not notice any discrimination that may be happening on the part of those without it, ${ }^{72}$ and that whether to have it or not should be a personal choice, not something that is enforced. ${ }^{73}$ This theme is adopted in Uglies where subjugation by authorities is claimed to be for the protection of society. The presence of lesions in the majority of people's brains keeps humanity in an idyllic state. Throughout the series, the ethics of this are questioned, and Tally comes to the conclusion that the Operation should be a personal choice. She tells Peris that though the authorities

\footnotetext{
70 “Liking”, 178.

71 “Liking”, 185.

72 “Liking”, 191.

73 “Liking”, 190.
} 
may have good reasons for changing people in this way, "Their reasons don't mean anything unless I have a choice, Peris. And they don't give anyone a choice."74

Westerfeld treats Chiang's text more creatively than the previously discussed texts. There are some direct (mimetic) similarities - such as being pretty, and the justifications for the operations. However, as Westerfeld describes his use of the text as reversing the system of beauty depicted in Chiang's work, inversions abound within his own series. The resemblance between the texts is clear, but individual aspects have been significantly altered. Westerfeld's complete reversal of elements suggests that he is presenting a different viewpoint to Chiang, and that he wishes to correct the precursor text, but such an assumption is confused both by his obvious admiration for the work which he deems "brilliant", ${ }^{75}$ and by the way both works reach the same conclusion. Though the works are similar, Westerfeld reinterprets Chiang's text for a different audience. Chiang's text, with an imagined adult audience, has many narrators who present different points of view so that the story focuses on the issue rather than the characters. A Young Adult text typically encourages the reader to identify with the protagonist, and Westerfeld's work though it presents the same issue as Chiang's work - takes the character Tally as its primary focus. The documentary style and shorter length of Chiang's work also means that it necessarily has a more skeletal plot than Westerfeld's, and the action of Uglies is more likely to appeal to a younger audience than "Liking What You See".

The Uglies series also resembles Ray Bradbury's novel Fahrenheit 451 and the equally renowned film adaptation (1966). It mirrors plot events of the earlier

\footnotetext{
${ }^{74}$ Pretties, 232.

${ }^{75}$ Mind-Rain, 155.
} 
work, uses fire as a motif, and adopts certain thematic aspects of Fahrenheit 451. In Bradbury's novel Montag saves four intact books from his burning house when he is running away from the firemen. ${ }^{76}$ Similarly, The Boss takes magazines from the burnt and captured Smoke, wanting to "save a precious piece of human heritage from these barbarians" ${ }^{77}$ The motif is similar in each, as is the motive - each character trying to save a piece of culture.

The film of Fahrenheit 451 refers to "the Book People", a group which is analogous to the Smoke. Clarisse says that the Book People live:

"Up in the farm country, the woods and the hills, they live there, in little groups. And the law can't touch them; they live quite peaceably and do nothing that's forbidden. Though if they came into the city they might not last long."78

People who live in the Smoke also live in the wild - "they don't put a wall up between themselves and nature", ${ }^{79}$ and live peaceably until they are discovered by the Specials - their activity, unlike the Book People's, is forbidden. They operate under their own social system, as the Book People do. David, who was born in the Smoke, is incompetent when he first goes to the city, and without Tally's assistance would not have 'lasted long'.

In Fahrenheit 451, Montag reads a book aloud to Linda and a group of her friends. ${ }^{80}$ In Specials, Zane pretends to read to a group of Crims - but he is in fact only reading to their interface rings:

“The others are off on a little trick tonight. I'm covering, in case the wardens are monitoring us."

\footnotetext{
${ }^{76}$ Fahrenheit, 118.

${ }^{77}$ Uglies, 291.

78 "Fahrenheit 451", DVD, directed by François Truffaut, (1966; Universal City, California: Universal Studios, 2003).

${ }^{79}$ Uglies, 92.

${ }^{80}$ Fahrenheit, 98-99.
} 
Shay laughed. "So the wardens are supposed to believe the Crims have a reading group?",81

Westerfeld inverts the book-reading's purpose as a plot device. Reading aloud to a group is illegal in Fahrenheit 451, but the "reading group" in Specials is designed to hide illegal activity from the authorities.

Fire is an important motif in Bradbury's novel, seen in the many occurrences of book-burning. To those on the side of the authorities it represents a cleansing of all that is dangerous to society, of all that causes upset and unhappiness. To Montag and the Book People, fire represents the authoritarianism and oppressiveness of their society. Though Westerfeld connects the book-burning with the loss of face in Uglies, his series also contains an actual book-burning. Tally and David return to the Smoke after its invasion:

Tally tried to picture what had stood there. Her knowledge of the Smoke had evaporated, the familiar streets reduced to an unrecognizable sprawl of ash and embers.

Then she saw a few blackened pages fluttering in the wind. The library.

"They didn't take the books out before they ...," she cried. "But why?,82

This book-burning too is representative of an oppressive society. David explains to Tally that the Specials burnt the books because "They don't want people to know what it was like before the operation." 83

There are three other times in the series where fire is an important motif, and each occasion reflects the role of fire in Fahrenheit 451. The first is at the Smoke when Tally throws the pendant Dr Cable gave her into a fire:

The pendant swung by its chain in her fist, sparkling red in the firelight. Tally focussed all her doubts on it, all her fear of discovery, her terror at Dr Cable's threats. She clutched the pendant, squeezing the unyielding metal until her muscles ached, as if forcing into her own

81 Specials, 80.

${ }^{82}$ Uglies, 330.

${ }^{83}$ Uglies, 330. 
mind the almost unthinkable fact that she might remain an ugly for life. But somehow not ugly at all. ${ }^{84}$

To Tally, throwing the pendant into the fire symbolises the destruction of her old life - her connections with Dr Cable, her doubts about the Smoke, and her fear of being an ugly for the rest of her life. She believes that by destroying the pendant she will no longer have to betray the Smoke, and can begin a new life there. (Ironically, of course, it has quite a different effect.) The destruction of an old life is also the role of fire in Fahrenheit 451, as it destroys the old life and culture in which books are read. The next instance occurs shortly afterwards, when fires destroys the Smoke during Special Circumstances' invasion. ${ }^{85}$ The correlation with Fahrenheit 451 is twofold: firstly, the fire destroys a free civilisation (one in which people are free to read books), and secondly, the authorities in each text use fire to achieve their ends. The third instance is in Specials. Andrew Simpson Smith uses fire to destroy the "little men", electronically charged dolls guarding his village, so that he can leave and discover what is outside. Fire in this instance is liberating, in contrast to the representation of fire in Fahrenheit 451. Despite the overarching portrayal of fire as oppressive in Bradbury's work, some of his characters - such as Beatty and the firemen - would consider fire liberating because book-burning creates a happy society. Bradbury subtly weaves two points of view - that fire is oppressive and that it is liberating - into his narrative. Westerfeld must be more explicit in portraying these different points of view as he is writing for a younger audience.

The cultures in both texts create shallow and empty-headed people. Clarisse laments that people in Bradbury's world do not talk about anything - everyone says the same thing, "They name a lot of cars or clothes or swimming-pools mostly and

\footnotetext{
${ }^{84}$ Uglies, 281.

${ }^{85}$ Uglies, 288.
} 
say how swell." 86 This is an obvious satire on consumerism, a topic touched on by Uglies, where people in the city can get anything they need from the hole-in-thewall. ${ }^{87}$ Clarisse's description could well describe the new-pretty culture, which, Westerfeld says:

Is best summed up by the language they spoke. In particular, new pretties reduced the huge number of words meaning 'good' or 'bad' to only two: 'bubbly' and 'bogus'. They could have whole conversations using hardly any other words, which shows how empty-headed the operation had made them. $^{88}$

In each scenario, people talk a lot - but about nothing of substance. The shallowness of the cultures is further evident in the importance of appearance. Mildred and her friends "talk politics" in Fahrenheit 451, saying that they are glad that the attractive President Noble won the campaign rather than his ugly opponent. ${ }^{89}$ In Uglies, of course, the entire culture is based on the desire to be beautiful.

Being shallow and empty-headed, people are easily bored. Bradbury's firemen, on a dull night, let animals loose and bet on which ones the mechanical hound will get first. ${ }^{90}$ Tally and a group of other new-pretties visit a skating rink, where Zane gets bored and tips a bottle of champagne over the ice, hoping that because alcohol has a lower freezing point than water - the ice might crack and send a skater tumbling. ${ }^{91}$ Each group of people employs a similar cure for boredom: hurting animals or people for their own entertainment.

As previously discussed, Westerfeld considers the book-burning in Bradbury's work and the Operation in his own as thematically similar, because both

\footnotetext{
${ }^{86}$ Fahrenheit, 36.

${ }^{87}$ Incidentally, Westerfeld deals intensively with the topic of consumerism in So Yesterday. (New York: Razorbill, 2004.)

${ }^{88}$ Bogus, 64-65.

${ }^{89}$ Fahrenheit, 96.

${ }^{90}$ Fahrenheit, 30-31.

${ }^{91}$ Pretties, 5.
} 
result in a loss of face and a loss of culture. The justifications for each, touted by those in authority, are also similar. The justification given for book-burning is that people must be happy, and to be happy they must be equal, and to be equal they must be alike. Beatty, the captain of the firemen, claims that books cause people to be unhappy. For every book, there are people who do not like it - he cites black people not liking Little Black Sambo, and white people not liking Uncle Tom's Cabin, and remarks to Montag:

"You must understand that our civilization is so vast that we can't have our minorities upset and stirred. Ask yourself, What do we want in this country, above all? People want to be happy, isn't that right? Haven't you heard it all your life? I want to be happy, people say." In the film, Beatty claims that those who read profound books believe themselves to be better than others, then remarks, "The only way to be happy is for everybody to be made equal. So we must burn the books, Montag. All the books. ${ }^{, 93}$ In Uglies, too, characters justify the Operation by saying that it makes people happy - both because they want to be pretty, and because the lesions put them in a happy state of mind.

Beatty explains further that equality does not mean "everyone born free and equal, as the Constitution says, but everyone made equal. Each man the image of every other; then all are happy, for there are no mountains to make them cower, to judge themselves against." ${ }^{, 94}$ Elements of this are picked up in Uglies. People are not born equal, they are created equal by the Operation, by which everyone is literally made "the image of every other". Before the Prettytime, people were judged on appearance, and pretty people got better jobs, and people were killed over "stuff like

\footnotetext{
${ }^{92}$ Fahrenheit, 62-63.

93 "Fahrenheit 451", DVD, directed by François Truffaut, (1966; Universal City, California: Universal Studios, 2003).

${ }^{94}$ Fahrenheit, 62.
} 
having different skin color." 95 People looking alike means that everyone is - in theory - equal.

Westerfeld summarises the authorities' justification for the Operation, which he had explained over the course of the series, in Bogus to Bubbly (2008), explaining that because making everybody pretty did not prevent fighting, the authorities needed to do something else to prevent war forever:

With small alterations to several areas of the brain, a new kind of pretty could be created: compliant, unaggressive, and happy, the perfect combination of sweet-tempered and just a bit lazy. Impossible to make into soldiers, bubbleheads could never go to war. Incapable of dealing with more than one child every few decades, they certainly wouldn't re-create Rusty overpopulation anytime soon. And they were unlikely to ever want to change the system that had made them so beautiful and so happy. Finally humanity could be kept in an idyllic state forever - the end of hardship and conflict had been reached at last. ${ }^{96}$

This explanation is similar to that offered in Fahrenheit 451. In each work, the official explanation is that being alike makes everybody happy, and society functions well as a result. The second, more sinister explanation explored in Westerfeld's text is that it is acceptable to modify people's brains for the good of society. This is implicit in Bradbury's work. While the authorities do not physically modify people's brains, they do modify them through not allowing them to read books, censoring the ideas they can be exposed to.

Both works are focalised through protagonists who are misfits in their societies. Though Tally and Montag face different circumstances they share the same point of view. In a culture where happiness is of the utmost importance, Montag must wear a mask to fit in:

\footnotetext{
${ }^{95}$ Uglies, 44.

${ }^{96}$ Bogus, 35.
} 
He was not happy. He was not happy. He said the words to himself. He recognized this as the true state of affairs. He wore his happiness like a mask and the girl had run off across the lawn with the mask and there was no way of going to knock on her door and ask for it back. $^{97}$

Tally must wear a mask to fit in in New Pretty Town. This is foreshadowed in Uglies, as she sneaks in to visit Peris, wearing a pig mask to hide the fact that she is an ugly and does not belong there. In Pretties, she wears a metaphorical mask. After her Operation, she does not act as a new-pretty ought to. Shay has an eye surge, and clocks that run backwards are implanted on her eyeballs. Tally asks her "Isn't that maybe one thing too many, Shay?"98 Shay accuses her of hating them, and Tally realises that she has made a social faux pas and assures Shay that they are "totally pretty-making", and that it is "good they go backward." She inwardly scolds herself, as "it was the kind of mistake only brand-new pretties made, and she'd had the operation over a month ago. Why was she still saying bogus things?" 99 Montag and Tally both mask their true feelings in order to adhere to the standard of behaviour that is expected in their societies.

Neither Tally nor Montag make decisions for themselves, despite their desire to do so. Montag complains to Faber, 'I'm not thinking. I'm just doing like I'm told, like always. You said get the money and I got it. I didn't really think of it myself. When do I start working things out on my own?"100 Tally, similarly, is disgruntled in Specials because "other people had made most of [her] choices for her ... everything else had happened because of threats, accidents, lesions in her brain, and surgery changing her mind for her."101 Each character believes that people are not fully

\footnotetext{
${ }^{97}$ Fahrenheit, 19.

${ }^{98}$ Pretties, 9.

${ }^{99}$ Pretties, 9.

${ }^{100}$ Fahrenheit, 92.

${ }^{101}$ Specials, 184.
} 
living unless they are making their own choices and in control of their own lives but this is not what either society wants for its citizens.

Westerfeld's use of Fahrenheit 451 is creative, but less blatantly so than his use of "Liking What You See", where direct opposites and correlations make the influence extremely evident. That is, it would be less blatant if Westerfeld had not taken care to explain to newspaper reviewers how he had been creative. The connection between book-burning and the Operation, if left unexplained, might not have been so easily drawn. Westerfeld appropriates and alters aspects of Bradbury's work, though not as dramatically as he does Chiang's. This apparent attempt at finetuning individual aspects of the text suggests an implicit critique of Bradbury's novel. Westerfeld's comments to Amanda Craig support this, as he draws attention to how he has changed Bradbury's story. The later work, however, does not surpass the original. The Operation, as a social engineering tool, is treated explicitly. It is obvious how it is used to control people's minds, and the justification for it is presented in an explicit manner. Bradbury's social engineering tool, book-burning, is less obvious - the author does not explain precisely how it results in people being controlled. By doing implicitly what Westerfeld does explicitly, Fahrenheit 451 (as it has an imagined adult audience) demonstrates a subtlety and sophistication which is absent in Uglies.

Westerfeld's silence regarding the similarities between Uglies and Brave New World is not because the influence is accidental or because he is unaware of Huxley. (In his 2009 novel Leviathan, Westerfeld names one of the genetically 
engineered creatures which populate the work a "Huxley" ${ }^{102}$ ) Rather, his silence may be due to the similarity of the works. Two aspects of Uglies are particularly comparable to Brave New World: the reservations which exist in each work, and the characters John Savage and Andrew Simpson Smith. Westerfeld's use of these is extremely mimetic, and he may worry that readers will assume he has merely copied Huxley's work. These extreme similarities, however, point towards elements of Uglies that draw on Huxley's text but are refunctioned so that the story becomes relevant to a Young Adult audience. The difference between the works is largely thematic. There is an overlap of themes between the texts, but Westerfeld places greater emphasis on those which he sees as Young Adult, paying particular attention to identity - which he considers the key feature of the genre:

The defining feature of the [Young Adult] genre is a set of themes: Issues of identity, of feeling uncomfortable in one's own skin and finding one's place in the world. Who am I? Where did I belong on this crazy planet? Who made these rules anyway? Clothes, language, ethics, friendship, history, even magic - in YA world, these subjects all become measures and means of self-definition. Of course, most YA has a teenage protagonist, and any realistic portrayal of a teenager will engage those questions naturally. ${ }^{103}$

There are several notable similarities between the Reservation in Huxley's work and the reservation in Westerfeld's work. There is no conditioning in either: inhabitants are not split into uglies and pretties, or Alphas and Epsilons. Those who live in Huxley's Reservation do not have access to soma, and those who live in Westerfeld's reservation do not have lesions in their brains. Old customs are

\footnotetext{
${ }^{102}$ Scott Westerfeld, Leviathan, (New York: Simon Pulse, 2009), 31-32. A further (probable) Huxley reference is made in Westerfeld's short story "Stupid Perfect World" (2008). Not only is the title a seeming nod to Brave New World but the central character Kieran is fond of Shakespeare (as John Savage is in Huxley's novel) and refers to the same "slings and arrows of outrageous fortune" passage in Hamlet as John Savage. ("Stupid Perfect World" in Love Is Hell, 55-112, (New York:

HarperCollins, 2008), 111, Brave New World, 214.)

${ }^{103}$ Justine Larbalestier and Scott Westerfeld, "Interview", 26 July 2006, http://slayground.livejour nal.com/113442. (accessed 23 November 2009).
} 
preserved in both reservations, and this would be hindered by the presence of any conditioning.

Each reservation is guarded and impossible to escape from. The Reservation in Brave New World is surrounded by "upwards of five thousand kilometres of fencing at sixty thousand volts", ${ }^{104}$ and Bernard and Lenina are informed that "To touch the fence is instant death". ${ }^{105}$ The reservation in Pretties is surrounded by what the inhabitants call "little men", but are actually small dolls fashioned from twigs and dried flowers. As Tally attempts to pass them she feels a tingling sensation which intensifies as she moves closer. The reader is told that "Her throat gagged on her next breath, as if the air were too electrified to breathe." ${ }^{106}$ Unable to physically move past the dolls, she realises that inside them is "a security system powerful enough to cripple human beings ... something that attacked the human nervous system, drawing an impassable border around the villagers' world." 107 This is Westerfeld's reworking of Brave New World's electric fence.

Though inhabitants cannot escape, people can get in. Each reservation experiences visitors from the outside world, who arrive by aircraft. Bernard and Lenina fly in on the Blue Pacific Rocket, and the scientists who visit Westerfeld's reservation arrive in hovercars. These visits in Uglies are the only contact that the inhabitants have with the outside world, and they believe the visitors to be gods, not realising that the world continues beyond the reservation. In Brave New World, the situation is similar. It is stated that "inspectors occasionally visit ... otherwise, [there is] no communication whatever with the civilized world". ${ }^{108}$ Tally remarks that the

\footnotetext{
104 Aldous Huxley, Brave New World, 1932. In Brave New World and Brave New World Revisited, 15-231, (New York: Harper Perennial, 2005), 98. (Hereafter referred to as Brave.)

${ }^{105}$ Brave, 99.

106 Pretties, 297.

107 Pretties, 298.

${ }^{108}$ Brave, 99-100.
} 
reservation in Pretties is merely "someone's pet anthropology project", ${ }^{109}$ and though this is not a direct echo of anything in Brave New World, Bernard does make notes about "the Savage" in an anthropological manner. ${ }^{110}$

Tally and Lenina, as visitors, are both outsiders in the reservations. Tally recognises that she does not belong there, imagining that Andrew wants to ask her "What the hell are you doing here?"111 As visitors, they react negatively to the inhabitants' displays of intimacy. When Lenina sees women breast feed their children, "The spectacle ... made her blush and turn away her face. She had never seen anything so indecent in her life." 112 Tally, in turn, is surprised to discover "that 'bed' was in fact a foreign concept [in the reservation]." ${ }^{113}$ Her reaction is also negative, as she finds the hut where they are sleeping "dizzying" and is surprised that they do not have any concept of privacy. ${ }^{114}$ The reactions of Lenina and Tally illustrate how different life and customs are inside and outside of the reservations.

The numerous correlations between the reservations make it obvious that Uglies was influenced by Brave New World. Much has been directly borrowed and not changed in any significant way. The same is true of similarities between the characters John Savage and Andrew Simpson Smith, the latter seeming to have been modelled on the former. Andrew is even referred to as a savage in the text, in an apparent, italicised nod to Huxley. Tally notices that "In seconds, Andrew Simpson Smith had changed from a grieving son into some kind of... savage."115 This duality of Andrew's character is displayed throughout the text. He is young, but is the "holy

\footnotetext{
${ }^{109}$ Pretties, 298.

${ }^{110}$ Brave, 148.

111 Pretties, 267.

${ }^{112}$ Brave, 106.

${ }^{113}$ Pretties, 272.

114 Pretties, 273.

115 Pretties, 279.
} 
man" of the community. He is described as "out to murder a random stranger" 116 to avenge his father's death, but on the next page has become "like an anxious-toplease puppy". ${ }^{117}$ Tally finds herself frustrated with his ability to make "brilliant leaps of insight" at the same time as being "as thick as could be expected from someone who thought the world was flat". ${ }^{118}$ Andrew's dualistic nature is a repetition of Huxley's portrayal of John Savage. As his name suggests, he is considered a savage - but he is also a lover of Shakespeare. He is seen reading poetry, and in the next instant "His cheeks burnt with the rush of blood, the room swam and darkened before his eyes" and he desires to kill Popé as he sleeps next to Linda. $^{119}$

Both John and Andrew learn about the outside world from their parents, John from his mother, and Andrew from his father. Each then leaves the reservation, believing that the world outside will be better. Both are ultimately disappointed, and reject that world too. John's dissatisfaction with the world outside the Reservation is evident as he recalls:

"Long evenings by the fire or, in summertime, on the roof of the little house, when [his mother] told him those stories about the Other Place, outside the Reservation: that beautiful, beautiful Other Place, whose memory, as of a heaven, a paradise of goodness and loveliness, he still kept whole and intact, undefiled by contact with the reality of this real London, these actual civilized men and women.",120

The "Other Place" is not what he has imagined it to be. As it has not met his expectations he rejects it, committing suicide at the close of the novel. Andrew also leaves the reservation optimistically, wanting to see what lies beyond. He finds

\footnotetext{
116 Pretties, 291.

${ }^{117}$ Pretties, 292.

118 Pretties, 308.

${ }^{119}$ Brave, 124.

${ }^{120}$ Brave, 182-183.
} 
himself dissatisfied with the authorities, so helps those who are running away to find the New Smoke. He asks Tally, "Do you still challenge the gods, Young Blood?"121 wanting to know if she is also dissatisfied, and is pleased when she answers in the affirmative. He too rejects the world he finds beyond the reservation, and in Extras (2007) is preparing to aid the establishment of a new civilisation in orbit. ${ }^{122}$

These direct resemblances between Huxley's and Westerfeld's novels show that Westerfeld's series was heavily influenced by the older text. Other aspects of Uglies are also imitative of Brave New World, but have been refunctioned so that the story becomes more relevant to a Young Adult audience. The focalisation of Uglies is through the teenage protagonist Tally, who bears a similarity to the character Bernard, from whose perspective Brave New World is presented. Neither character fits into their society. Bernard finds himself having to lie after a group singing of Orgy-porgy. Participants are expected to find this wonderful, and Bernard is asked three times whether he found it so: “'Yes, I thought it was wonderful,' he lied, and looked away; the sight of her transfigured face was at once an accusation and an ironical reminder of his own separateness." ${ }^{, 123}$ Bernard is aware that his reaction is unacceptable; that it sets him apart and makes him different in a society where difference is not tolerated. Tally has a similar experience as a pretty, where she realises that she is still saying "bogus" things that a pretty should not say, and that she is acting in a way she should not. Unexcited about Peris and Fausto's costume idea for a party, she voices her criticism. Shay gives Tally a look "like she was saying something bogus again." Tally chastises herself, thinking "Stupid Tally. The

\footnotetext{
${ }^{121}$ Specials, 161.

122 Scott Westerfeld, Extras, (New York: Simon Pulse, 2007), 389. (Hereafter referred to as Extras.)

${ }^{123}$ Brave, 86.
} 
costumes really were bubbly." different to those around her, and that this requires disguise.

In each society, absolute power is in the hands of a few, and they use similar controlling tactics. In Brave New World the few are the ten world controllers, while in Uglies they are Special Circumstances. Special Circumstances features more heavily than the world controllers, and this focus allows Westerfeld to deal with the question "who made these rules anyway?" which he considers an important theme in Young Adult literature. ${ }^{125}$ Exercising his control, world controller Mustopha Mond stops a paper entitled "A New Theory of Biology" from being published because it is "novel and highly ingenious, but heretical, and, so far as the present social order is concerned, dangerous and potentially subversive." ${ }^{126}$ Maddy recalls a similar occurrence after she and Az discovered the lesions:

"Not long after our discovery, Special Circumstances paid a visit. They took our data and told us not to look any further or we'd lose our licenses. It was either run away, or forget everything we'd found."127

There is no difference between the tactics used - in each case the authorities halt the publication of information that may unsettle the status quo. However, in Uglies Tally responds to and questions the information. This allows the text to engage more overtly with ethical questions than an adult text might.

A further theme shared by the texts is that of conditioning, and in each world this is done in two parts: mind and body. In Brave New World embryos are physically conditioned to be a particular class of human, and people are taught as children to like the way they have been made:

\footnotetext{
124 Pretties, 13.

125 Justine Larbalestier and Scott Westerfeld, “Interview”, 26 July 2006, http://slayground.livejo urnal.com/113442. (accessed 23 November 2009).

${ }^{126}$ Brave, 162.

${ }^{127}$ Uglies, 266-277.
} 
"And that," put in the Director sententiously, "that is the secret of happiness and virtue liking what you've got to do. All conditioning aims at that: making people like their unescapable social destiny."128

Soma, the drug taken to induce a pleasant emotive state, is also a part of conditioning. The lesions in Westerfeld's work are similar, creating a similar state of being in people. Conditioning in Westerfeld's work has further similarities with the conditioning in Huxley's. The Operation physically moulds people into pretties, and society is constructed in order to make people want to be pretties. Anyone who does not want to become pretty does want to be so after they had have the Operation, as the lesions also contribute to conditioning. Although this is not stated explicitly within the text, as it is in Brave New World, it is shown by the change in Shay after she has the Operation. As an ugly, she was resistant:

"I don't want to be pretty ... I'm sick of this city ... I'm sick of the rules and boundaries. The last thing I want is to become some empty-headed new pretty, having one big party all day.",129

After the Operation, she enjoys being a pretty, and declares, "I like the way I look ... I'm happier in this body ... I feel bubbly. It's nice not being all raging with hormones." 130

During a conversation with Mond, John Savage describes what could be a society of pretties, which shows how similar the societies are in each text:

"Charming! But in civilised countries," said the Controller, "you can have girls without hoeing for them; and there aren't any flies or mosquitoes to sting you. We got rid of them all centuries ago."

The Savage nodded, frowning. "You got rid of them. Yes, that's just like you. Getting rid of everything unpleasant instead of learning to put up with it. Whether 'tis better

${ }^{128}$ Brave, 26.

${ }^{129}$ Uglies, 83.

${ }^{130}$ Uglies, 408. 
in the mind to suffer the slings and arrows of outrageous fortune, or to take arms against a sea of troubles and by opposing end them ... But you don't do either. Neither suffer nor oppose. You just abolish the slings and arrows. It's too easy.",131

The world in Uglies is similar. Observing pretties throughout the series, the reader learns that they do not have to experience anything that is truly unpleasant. Like John, Tally and the Crims wish to experience authentic sensations. Dr Cable tells Tally:

"We at Special Circumstances know all about sensations, especially the ones you and your so-called Crims are always searching for. I can give it to you, Tally. All day, every day, bubblier than you can imagine. The real thing. Not just an escape from the haze of being pretty - something better."132

Without access to these sensations, pretties experience manufactured emotions, and live in a permanent happy daze which is created by the lesions in their brains. The character Lenina would easily fit into the pretty world. Harold Bloom would say that this is a result of the anxiety of influence come full circle, with the precursor's work (Huxley's) being defined in terms of the current writer's work (Westerfeld's). ${ }^{133}$ Lenina, too, is concerned only with feeling good, rather than with what actually exists. She prefers the soma-induced "jolly" to the "dreadful ideas" that can be found in reality. ${ }^{134}$ The theme of manufactured emotions plays a bigger role in Westerfeld's work than it does in Huxley's where it is represented by Lenina's experiences. In Westerfeld's work it is experienced by pretties, as a collective group of people, and through the protagonist as a pretty. Westerfeld's extension of this theme in his work is likely to be because it is a further aspect associated with the theme of identity and the authentic self.

\footnotetext{
${ }^{131}$ Brave, 213-214.

132 Pretties, 133.

133 Anxiety, 141.

${ }^{134}$ Brave, 91.
} 
Beauty is a theme in each work, and Westerfeld adopts three aspects of this from Huxley. The first is that beauty is created. Lenina looks at a boy and wishes that his ears were smaller, and wonders whether "perhaps he'd been given just a spot too much parathyroid at Metre $328 ? " 135$ This implies that appearance is controlled, as it is in Uglies, where beauty is created through a scientific process. Secondly, ugliness is undesirable in both texts. In Brave New World this is evident in Lenina's reaction to a woman she encounters in the Reservation:

Lenina noticed with disgust that two of the front teeth were missing. And the colour of the ones that remained ... She shuddered. It was worse than the old man. So fat. And all the lines in her face, the flabbiness, the wrinkles. And the sagging cheeks, with those purplish blotches. And the red veins on her nose, the bloodshot eyes. And that neck - that neck; and the blanket she wore over her head - ragged and filthy. And under the brown sack-shaped tunic those enormous breasts, the bulge of the stomach, the hips. Oh, much worse than the old man, much worse! ${ }^{136}$

In Uglies ugliness is also undesirable. Uglies eagerly await turning sixteen so that they can have the Operation and become pretty. When Tally has sneaked into New Pretty Town as an ugly, she realises that she is worth nothing there, and that "Worse, she was ugly." 137 In her culture, being ugly is worse than anything else. Though she desires to be worth something, her desire not to be ugly is even greater. Thirdly, ugliness and ugly people are difficult to look at in both societies. Linda's unattractive appearance is noted as being "by far the strongest reason for people's not wanting to see [her]." ${ }^{\text {138 }}$ As a pretty, Tally does not want to look at David, an ugly, as "his face sent a shock through her. Not because he was hideous - he wasn't - but because he

\footnotetext{
${ }^{135}$ Brave, 63.

${ }^{136}$ Brave, 112.

${ }^{137}$ Uglies, 7.

${ }^{138}$ Brave, 142.
} 
was simply ... unimpressive. Not an ugly prince. Just ugly." ${ }^{\prime 139}$ While these three aspects of beauty exist in each work, in Westerfeld's it is a major theme, but only a minor one in Huxley's. Westerfeld has made the theme more important, because beauty (and the social acceptance and admiration that come with it) is a teenage concern, more befitting a Young Adult than an adult text.

Social stability is an important theme in each work, represented most explicitly by Bokanovsky's Process and the Operation. In Brave New World a character states that "Bokanovsky's Process is one of the major instruments of social stability". ${ }^{140}$ This is a process where fertilised human eggs are split into a large number of identical genetic copies, resulting in a large number of identical twins. It allows the government to control the population, ensuring that the right number of people are created, and that they are the type of people society needs. The Director of Hatcheries laments that "If we could bokanovskify indefinitely the whole problem would be solved." ${ }^{141}$ In Uglies, because of the regulations regarding post-Operation appearance, everyone does look the same - as if society has bokanovskified indefinitely. The result is the same, though the procedures are different. Their purposes differ also - Bokanovsky’s Process is used to stabilise the population, but the main purpose of the Operation is to make everybody equal by virtue of looking alike. In turn, the thematic significance of each is different. Both relate to social stability, but Westerfeld has incorporated the theme of appearance. This relates to identity - which he has named as the defining feature of the Young Adult genre. ${ }^{142}$

A caste system operates in each society, and the one in Uglies is a significant refunctioning of Huxley's Alpha to Epsilon system. In Uglies, people can and do

\footnotetext{
139 Pretties, 324.

${ }^{140}$ Brave, 18.

141 Brave, 19.

142 Justine Larbalestier and Scott Westerfeld, “Interview”, 26 July 2006, http://slayground.livejou rnal.com/113442. (accessed 23 November 2009).
} 
move classes, which they cannot do in Brave New World. It is expected and required of uglies to become pretties, and pretties who possess the required skills and abilities are chosen to become Specials. Because the caste system operates in this way, Westerfeld is able to use it to explore the theme of identity. Tally goes through both the transition from ugly to pretty, and pretty to Special. A teenage reader going through the transition of childhood to adulthood is therefore able to identify with the character and issue. Part of the conditioning in Brave New World is that people are made to accept the class of person that they are. Lenina muses, "I suppose Epsilons don't really mind being Epsilons", and Henry replies, "Of course they don't. How can they? They don't know what it's like being anything else."143 The parallel between this and Uglies is interesting, because while pretties enjoy being pretties (and, not remembering their ugly days, ${ }^{144}$ do not know anything else), uglies do not enjoy being uglies. David tells Tally that this is "the worst thing they do to you, to any of you. Whatever those brain lesions are all about, the worst damage is done before they even pick up the knife: You're all brainwashed into believing you're ugly." the confrontation of desire with knowledge. This is an aspect of Children's Literature identified by Perry Nodelman in his book The Hidden Adult (2008). Nodelman explains that Children's Literature tends to disguise didactic intentions inside stories where pleasures are desired and then gained. The protagonist, having received what they wanted, often discovers that it is undesirable. ${ }^{146}$ Tally desires to be pretty, but learns through the course of the first book that being pretty is not the wonderful, lifechanging occurrence that she had imagined. In a Young Adult text, Nodelman

\footnotetext{
143 Brave, 77.

${ }^{144}$ Pretties, 65.

${ }^{145}$ Uglies, 276.

${ }^{146}$ Perry Nodelman, The Hidden Adult: Defining Children's Literature, (Baltimore, Md: John Hopkins University Press, 2008), 49. (Hereafter referred to as Hidden.)
} 
contends, while the protagonist learns that what they desired is undesirable, the adult knowledge and experience they gain through this occurrence offers no more certainty or security than their childhood innocence had. ${ }^{147}$ Though Tally realises that being pretty is undesirable, the alternative is not risk-free either. An alternative to the pretty society is established at the conclusion of Specials, and Tally worries that this too will be troublesome, stating "freedom has a way of destroying things." 148

There is no doubt that Westerfeld was influenced by Brave New World in writing the Uglies series, and it is understandable that he should worry about drawing attention to this, as the similarities are so numerous. However, while it may appear upon a first reading that he has merely copied aspects of Huxley's work and called them his own, he has done more than this. He has attempted to make the story one that has meaning for a contemporary teenage audience. This endeavour has been a successful one, as many of the aspects shared between the works function in different ways or draw the reader's attention to different themes.

A developing degree of influence can be traced through Uglies' four named influences. Westerfeld's adoption of the main features of "The Beautiful People" is mimetic and obvious. His use of the Tripods series is similarly mimetic, but less obvious as the texts do not share the same setting. He is creative in his use of "Liking What You See", and inversions and reversals of the original text appear in Uglies. His creative use of Fahrenheit 451 is more subtle, as the connection between book-burning and cosmetic surgery is not an obvious one.

\footnotetext{
${ }^{147}$ Hidden, 58.

${ }^{148}$ Specials, 371.
} 
The unmentioned influence, Brave New World, is situated at both ends of the spectrum. The many direct correlations between the reservations in each work, and the characters John Savage and Andrew Simpson Smith, display an influence more mimetic even than that of "The Beautiful People". It is perhaps these extreme similarities which discouraged Westerfeld from acknowledging this influence. However, they also point towards the refunctioning of Brave New World which Uglies performs, an activity which sits at the creative end of the spectrum. In this regard, his use of Brave New World is Westerfeld's most sophisticated use of a precursor text.

Westerfeld has varying degrees of success at surpassing his individual influences, but Uglies does transcend its influences as a collective body of texts. The series does not have a parasitical relationship with its precursor texts, depending on them to give it its meaning (as, for example, Paradise Lost relies on the reader's knowledge of Genesis). The series can be understood in its entirety without a knowledge of any of the precursor texts. However, many significant aspects of Westerfeld's series have evolved from aspects of the precursor texts. Though Westerfeld's work can be understood without knowledge of its influences, it would not exist without them. 


\title{
Chapter Two \\ The Nectar Collector: Literary Influences on Philip Pullman's His Dark Materials
}

\begin{abstract}
I have stolen ideas from every book I have ever read. My principle in researching for a novel is "Read like a butterfly, write like a bee", and if this story contains any honey, it is entirely because of the quality of the nectar I found in the work of better writers. But there are three debts that need acknowledgement above all the rest. One is to the essay On the Marionette Theatre by Heinrich von Kleist, which I first read in a translation by Idris Parry in the Times Literary Supplement in 1978. The second is to John Milton's Paradise Lost. The third is to the works of William Bake. ${ }^{149}$
\end{abstract}

Were this acknowledgement placed at the beginning of Northern Lights (1995) rather than the end of The Amber Spyglass (2000) a conscientious reader - knowing that Philip Pullman has described himself on different occasions as an atheist and an agnostic - might be surprised that he considers these works the greatest literary influences on His Dark Materials (1998-2005). All three can be considered religious texts though they differ in their alignment with orthodox Christianity. Paradise Lost (1667) retells the biblical story of the Fall of Man. The author proposes to "justifie the wayes of God to men", ${ }^{150}$ indicating that the poem will follow Christian doctrine. Kleist's 1810 essay portrays the Fall positively, as consciousness and knowledge replace grace and innocence, bringing humankind to a higher state of existence. Religious themes underpin Blake's work but they are not those of traditional Christianity.

Pullman uses each of these texts differently. Of William Blake, he remarks that though he is a great admirer of his work "I am not a Blake scholar, and there are

\footnotetext{
149 Spyglass, 549-550.

${ }^{150}$ John Milton, Paradise Lost, 1667. In The Poetical Works of John Milton, edited by H. C. Beeching, 173-448, (Oxford: Oxford University Press, 1919), I:26. (Hereafter referred to as Paradise Lost.)
} 
large stretches of the prophetic books that I have never read and probably never shall." 151 Though he agrees with some themes of Blake's poetry he realises that "this credo of mine is highly selective ... it would be possible to put together passages from Blake to support a quite different set of propositions." ${ }^{\text {"52 }}$ Allusions to Blake run through His Dark Materials, but Pullman does not deal with Blake's oeuvre as a whole. He adopts and changes aspects of the earlier works but ignores aspects which would not add to his own story. His Spectres and daemons owe a debt to Blake's Spectres and emanations, and he borrows from Blake the depiction of innocence and experience. Pullman also imitates Blake in his response to Paradise Lost, particularly in the representation of God.

Pullman's use of Kleist's essay is more structured. He describes Kleist's work as depicting:

The difference between innocence and experience: the contrast between the unconscious grace of a child, an animal, or a puppet, and the clumsy self-consciousness of those who are older, further from the inanimate, more tangled in the nets of reason and thought. ${ }^{153}$

The same theme is present in His Dark Materials and is explicitly illustrated in the way Lyra reads her alethiometer. She reads it first by unconscious grace but after her Fall - when she is subject to reason and thought - she must read it through knowledge. Each work also features a fighting bear, and Pullman admits "at one point I stole an incident involving Kleist's bear and gave it to mine." ${ }^{154}$ Pullman's

\footnotetext{
${ }^{151}$ Philip Pullman, “An English Visionary”. New Statesman 18 December 2006, http://www.newstatesman.com/200612180060. (accessed 8 October 2009). (Hereafter referred to as "Visionary".

152 "Visionary".

${ }^{153}$ Philip Pullman, "Folio Society Edition of His Dark Materials Preface”, http://www.philip-pullma n.com/pages/content/index.asp?PageID=119. (accessed 13 February 2010). (Hereafter referred to as "Folio Society Preface").

154 "Folio Society Preface".
} 
uses of Kleist's theme and bear are mimetic, as they are not significantly altered in his own work.

His Dark Materials is a careful and deliberate misreading of Paradise Lost which can be seen to follow the "map of misreading" developed by Harold Bloom in A Map of Misreading (1975). Pullman's trilogy adopts the main structure of Milton's epic, describing the rebellion against God and war on Heaven, the Fall of Man, and a harrowing of Hell. However, aspects of the precursor work are absent or adjusted so that the overall vision of Pullman's work is significantly different to Milton's. The glaringly obvious difference is that God, in Pullman's work, is no longer the ultimate force of good, and nor is Satan the ultimate force of evil.

There is another unavoidable influence on His Dark Materials, though it is not one of the three mentioned. Pullman's work bears a striking resemblance to another children's series which also begins with a young girl (whose two syllabic name begins with "L" and has four letters) hiding in a wardrobe. While in the wardrobe, Lyra - like the Pevensie children in C. S. Lewis's The Chronicles of Narnia (1950-1956) - takes a full length fur robe off its hanger, but as she does Pan warns her against becoming too comfortable:

"You should have used a scratchy old one," whispered Pantalaimon. "If you get too comfortable you'll go to sleep." ${ }^{155}$

This warning should also be heeded by readers who recognise the Narnia connection and expect a Narnia-like story - don't get too comfortable. Pullman, who once referred to Lewis as "the tweedy medievalist" before calling the Narnia series "one of the most ugly and poisonous things I've ever read", ${ }^{156}$ is an unlikely candidate to

\footnotetext{
${ }^{155}$ Philip Pullman, Northern Lights, (1995; repr., London: Scholastic, 1998), 19. (Hereafter referred to as Lights.)

${ }^{156}$ Philip Pullman, “The Dark Side of Narnia”, The Guardian 1 October 1998, http://www.crlamppo st.org/darkside.htm. (accessed 4 August 2009). (Hereafter referred to as "Darkside".)
} 
tell a similar tale. Instead he writes back correctively (in his opinion) against Narnia. However, he appears to be so incensed by the Christianity propelled in Lewis's work that he becomes blinded to the story, erroneously interpreting it. Despite the tenuous basis of his criticism, His Dark Materials misreads Lewis's series as it does Paradise Lost, swerving from and correcting the original text.

Pullman adopts and adapts aspects of Blake's poetry in his trilogy. His Dark Materials features malicious creatures known as Spectres, and beings of the same name are scattered throughout Blake's poetry, suggesting that Pullman borrowed something of Blake's depiction to use in his own work. Pullman's development of these creatures is collectively more cohesive than Blake's, as it is contained within the trilogy while Blake's depiction changed over time and between poems Pullman's books must link together while Blake's poems stand on their own. However, characteristics of Pullman's Spectres can be seen to have a precedent in Blake's Spectres.

Pullman's Spectres are described as "spectral forms that [drift] like mist", something to be distrusted as they are "full of malice". ${ }^{157}$ Early Blakean occurrences also suggest a negative or evil association. In "America" (1793), the Spectre is associated with blood as Blake describes how "The Spectre glowed, his horrid length staining the temple long / With beams of blood". ${ }^{158}$ The Spectre in "Europe" (1794) is also negatively portrayed, associated with entrapment, shadows, curses, and prohibitions:

\footnotetext{
${ }^{157}$ Knife, 134.

${ }^{158}$ William Blake, “America” (1793), 35-36. In Blake: The Complete Poems, edited by W. H. Stevenson. $3^{\text {rd }}$ Ed. (London: Pearson Longman, 2007.) (All subsequent Blake references are from this collection unless otherwise specified.)
} 
Every house a den, every man bound; the shadows are filled

With spectres, and the windows wove over with curses of iron.

Over the doors Thou shalt not, and over the chimney Fear is written. ${ }^{159}$

Spectres, in His Dark Materials, are spiritual beings which attack adults, feeding on the Dust that covers them. Adults attacked by Spectres "get pale and they stop moving. They still alive, but it's like they been eaten out from inside. You look in they eyes, you see the back of they heads. Ain nothing there." ${ }^{\prime 60}$ Observing an attack, Serafina Pekkala sees that there "ain nothing there" as a victim indifferently watches his son drown. ${ }^{161}$ Stanislaus Grumman explains that Spectres are repelled by the innocence of children, and feast instead on the human consciousness and Dust that children do not have:

"The Oblation Board and the Spectres of Indifference are both bewitched by this truth about human beings: that innocence is different from experience. The Oblation Board fears and hates Dust, and the Spectres feast on it, but it's Dust they're both obsessed by." 162

Because human consciousness and Dust enable humans to discover their sexuality and, as Will and Lyra do, fall in love, the Spectres' attacks can be considered attacks against love. This is supported by what Joachin Lorenz tells Serafina Pekkala and Ruta Skadi about Spectres:

"At any moment a father might be taken, or a mother, and the family fall apart; a merchant might be taken, and his enterprise fail, and all his clerks and factors lose their employment; and how can lovers trust their vows? All the trust and all the virtue fell out of our world when the Spectres came.",163

\footnotetext{
${ }^{159}$ William Blake, "Europe" (1794), 132-134.

${ }^{160}$ Knife, 62.

${ }^{161}$ Knife, 136.

${ }^{162}$ Knife, 292. The statement that "innocence is different from experience" is, of course, a cue from Blake's Songs of Innocence and of Experience (1794).

${ }^{163}$ Knife, 141.
} 
This sentiment recalls Blake's description of the Spectre as "the enemy of conjugal love". ${ }^{164}$ Morton Paley, in his commentary on "Jerusalem", suggests that the Spectre is also the enemy of sexual joy, ${ }^{165}$ citing the Spectre's speech in plate 88 :

"The Man who respects Woman shall be despised by Woman,

And deadly cunning \& mean abjectness only shall enjoy them.

For I will make their places of joy \& love excrementitious,

Continually building, continually destroying in family feuds ..."166

The attack on conjugal love, and the broken family from Blake's "family feuds", are akin to the broken families in His Dark Materials of soulless parents and "Spectreorphan" children. ${ }^{167}$ Spectres are, in each work, enemies of love.

Contact with Spectres in Pullman's world is ghastly. Attacked, Lena Feldt feels despair and weariness:

Her last conscious thought was disgust at life ... the world was not made of energy and delight but of foulness, betrayal, and lassitude. Living was hateful and death was no better ... thus she stood ... indifferent, dead in life. ${ }^{168}$

In Blake's mature depiction of Spectres, however, contact is desirable. Spectres are an element of divided man and are not completely evil, as the ideal situation for man is the fusion of their different elements. Los argues with his Spectre throughout "Jerusalem" (1804) but the two cooperate toward the end of the poem:

Holding his iron mace, the Spectre remains attentive.

Alternate they watch in night, alternate labour in day,

Before the furnaces labouring, while Los all night watches

\footnotetext{
${ }^{164}$ William Blake, 23 October 1804, "Letter to William Hayley". In The Letters of William Blake, edited by Frederick Tatham and Archibald George Blomefield Russell, 168-172, (New York: C. Scribner's sons, 1906), 170. http://www.archive.org/stream/letterswilliamb00tathgoog. (accessed 13 February 2010).

${ }^{165}$ Morton D. Paley, The Continuing City: William Blake's Jerusalem, (Oxford: Clarendon Press, 1983), 259.

${ }^{166}$ William Blake, "Jerusalem, Emanation of the Giant Albion" (1804), P1.88: 37-40. (Hereafter referred to as "Jerusalem".)

${ }^{167}$ Knife, 142.

${ }^{168}$ Knife, 329.
} 
The stars rising \& setting, \& the meteors \& terrors of night. ${ }^{169}$

The final plate of the poem comprises an illustration showing Los standing in front of a dragon temple, holding a hammer in one hand and a compass in the other. Two figures labour with him, his Spectre and emanation, united as they ought to be. This significant difference between Blake's Spectres and Pullman's shows that the latter has only adopted aspects that will fit with the worldview presented in his story.

Pullman's trilogy memorably begins "Lyra and her daemon", ${ }^{170}$ and daemons are an important part of both the plot and the depiction of human beings throughout the series. Like their depictions of Spectres, Pullman's description of daemons remains constant while Blake's emanations change throughout his poetry, but similarities between the two indicate that Blake's emanations influenced Pullman's daemons.

Emanations and daemons are both physical embodiments of an aspect of their human. Typically, emanations are feminine counterparts of males, reminiscent of males in His Dark Materials having female daemons (and vice versa). An emanation is an aspect of the divided man. "The First Book of Urizen" (1794) depicts Los's emanation Enitharmon being born from him. She emerges as a drop of blood and develops into a female form. ${ }^{171}$ The creation of Will's daemon is similar. Lyra is surprised, meeting Will for the first time, that he does not have a daemon. After realising that he is not like a child severed from his daemon she declares "You have got a daemon ... inside you." She elaborates:

169 “Jerusalem” P1.83: 78-81.

${ }^{170}$ Lights, 3.

${ }^{171}$ William Blake, “The First Book of Urizen” (1794), 308 - 315. 
"You wouldn't be human else. You'd be ... half dead. We seen a kid with his daemon cut away. You en't like that. Even if you don't know you've got a daemon, you have ... Your daemon en't separate from you. It's you. A part of you."172

His daemon, like Enitharmon, becomes externalised and is seen as a physical being at the end of The Amber Spyglass. Kirjava explains that she has been "torn away from [Will's] heart"173 - similar to Enitharmon emerging from Los as a drop of blood.

Typically, emanations are subservient to humans. Blake wrote in his essay "A Vision of the Last Judgement" (1810) that "In Eternity Woman is the Emanation of Man she has No Will of her own There is no such thing in Eternity as a Female Will". ${ }^{174}$ This is extreme subservience, but a lesser type is seen in the relationship between Los and Enitharmon. Throughout "Jerusalem" Enitharmon tries to assert dominion over Los, but he remains superior. She opposes him in plate 87 after he has asked for help:

Enitharmon answered "No! I will seize thy fibres \& weave

Them - not as thou wilt but as I will ...

... Be thou assured I never will be thy slave."175

Ultimately Enitharmon succumbs to Los's will and - along with his Spectre - is integrated into harmony with him. Daemons, too, are subservient to humans. Exploring the Retiring Room with Lyra, an agitated Pan requests that they leave, but is ignored. Shortly afterwards, as the pair are stuck hiding in the wardrobe, Pan says to Lyra "We're going to have to stay here now. Why don't you listen to me?" ${ }^{176} \mathrm{He}$

\footnotetext{
${ }^{172}$ Knife, 26.

173 Spyglass, 500.

${ }^{174}$ William Blake, “A Vision of the last Judgment", 1810. In The Complete Poetry and Prose of William Blake, edited by David V. Erdman, 554-556, (New York: Anchor Books, 1982), 562.

175 Blake, "Jerusalem", Pl.87: 12-15.

${ }^{176}$ Lights, 7.
} 
had seemingly advised that they not enter the Retiring Room, but as the dominant party Lyra had chosen to ignore his advice.

A central plot point in The Amber Spyglass is the separation of Will and Lyra from their daemons. The separation, felt by all parties emotionally and physically, has a precedent in Blake. Will, Lyra, and Pan are each devastated when they must leave their daemons behind in the land of the dead. Appalled, Lyra cries "passionate sobs" ${ }^{177}$ as she departs, and Pan clings to her, digging his claws into her clothes as she weeps. Though he cannot see his daemon, Will notes that "there was nothing worse to feel"178 as he leaves this invisible part of himself behind on the shore. The title character of Blake's "Ahania" (1795) is similarly devastated to be separated from Urizen. The emanation is left "Hopeless, abhorred, a death-shadow, / Unseen, unbodied, unknown, / The mother of Pestilence." ${ }^{179}$ She laments, "Weeping upon the void" ${ }^{180}$ distraught at the great abyss between the two of them. "The Four Zoas" sees the separation of Tharmas and his emanation, and man and emanation are miserable:

[Enion] sat among the rocks,

Singing her lamentation. Tharmas groaned among his clouds

Weeping, then bending from his clouds he stooped his innocent head,

And stretching out his holy hand in the vast deep sublime,

Turned round the circle of destiny with tears $\&$ bitter sighs ... 181

There is also a physical pain of separation. Lyra is all too keenly aware of Pan's absence, feeling "as if her skin had turned into lace and the damp and bitter air could flow in and out of her ribs, scaldingly cold on the raw wound where

\footnotetext{
177 Spyglass, 296.

178 Spyglass, 300.

${ }^{179}$ William Blake, “The Book of Ahania" (1795), 41-43. (Hereafter referred to as "Ahania”.)

180 “Ahania", 167.

${ }^{181}$ William Blake, “The Four Zoas" (c.1797), I: 62-66. (Hereafter referred to as "Zoas”.)
} 
Pantalaimon had been." 182 In the fourth night described in "The Four Zoas" (c.1797), Tharmas has a quarrelsome meeting with Los, after which he carries Los's emanation away. Both Los and Enitharmon feel the separation. She has a "bleeding wound", while Los:

... howled at the rending asunder! All the fibres rent,

Where Enitharmon joined his left side, in griding pain.

He falling on the rocks bellowed his dolour, till the blood

Staunched $\ldots{ }^{183}$

In both instances the separation results in a wound. Enitharmon and Los are both left bleeding, and Lyra feels the pain of a (metaphorical) wound where her daemon had been.

Blake's poetry often alludes to Milton or Paradise Lost. His response to the poem changed over time ${ }^{184}$ but his most straightforward (though extremist) interpretation of the epic is found in "The Marriage of Heaven and Hell" (c. 1790). In this poem the Devil speaks of Paradise Lost and his comments are deliberately provocative and inflammatory. He begins:

Those who restrain desire do so because theirs is weak enough to be restrained; and the restrainer or reason usurps its place and governs the unwilling.

And being restrained it by degrees becomes passive, till it is only the shadow of desire.

The history of this is written in Paradise Lost, and the governor (or reason) is called Messiah. $^{185}$

Shortly afterwards he asserts that "[Milton was] of the Devil's party without

\footnotetext{
182 Spyglass, 303.

183 "Zoas", IV: 59-62.

${ }^{184}$ This is reflected in his portrayal of the relationship between himself and Milton in Blake's poem "Milton" (c.1810-11).

${ }^{185}$ William Blake, "The Marriage of Heaven and Hell" (c. 1790), II: 29-35. (Hereafter referred to as "Marriage".
} 
knowing it", ${ }^{186}$ suggesting that the poet's sympathies lie with Satan rather than with God or Christ. These comments indicate "Blake's early assessment of the castrating effects of religious orthodoxy upon the intellectual and imaginative vision of even a strong poet", ${ }^{187}$ a theme which is present in His Dark Materials.

The church, as Pullman presents it, is an instrument of religious oppression, particularly in regard to intellectual vision and the search for knowledge. Throughout the series the church takes actions which will prevent individuals gaining knowledge. It is the church that sets up the Oblation Board which severs children from their daemons, thus preventing them from growing up and acquiring consciousness. Lord Asriel is exiled to Svalbard because the church does not want him to acquire "dangerous" knowledge through his experiments in Dust. Representatives of the Magisterium "act as a censor and suppress the news of any heretical discoveries", ${ }^{188}$ as the church would rather people believe official doctrine than search for truth. In short, the church oppresses people so that they do not challenge or threaten their authority, preventing them from taking action against the church so that any disgruntlement is "passive", merely a "shadow of desire."

Blake depicts a fortunate fall, or gain through loss, in book two of "The Four Zoas":

\footnotetext{
"What is the price of experience? Do men buy it for a song,

Or wisdom for a dance in the street? No: it is bought with the price

Of all that a man hath, his house, his wife, his children.

Wisdom is sold in the desolate market where none come to buy,

And in the withered field where the farmer ploughs for bread in vain.",189

186 "Marriage", II: 53-54.

${ }^{187}$ Stephen C. Behrendt, The Moment of Explosion: Blake and the Illustration of Milton, (Lincoln: University of Nebraska Press, 1983), 69.

${ }^{188}$ Knife, 130.

189 “Zoas", II: 607-611.
} 
To gain experience man must forgo something significant. Lyra's situation is similar. After her Fall she gains an awareness of her sexuality and a new level of relationship with Will as she grows up to be a 'child-no-longer-child', but it comes at a price. She loses her innocence and unconscious grace, seen in her losing the ability to read the alethiometer. It is a significant loss for Lyra, as the price of a man's house, family, and food would be. Lyra is first bewildered at the loss of this ability, then her bewilderment turns to desperation:

She turned away and clung to Will and said desperately:

“It's no good - I can tell - it's gone for ever - it just came when I needed it, for all the things I had to do ... Oh, it's gone, Will! I've lost it! It'll never come back!”

She sobbed with desperate abandon. ${ }^{190}$

In each case, something must be lost for something to be gained.

Pullman takes from Blake the notion of the serpent as counsellor. Enion laments in "The Four Zoas" that:

"I have planted a false oath in the earth, it has brought forth a poison tree;

I have chosen a serpent for a counsellor, \& the dog

For a schoolmaster to my children."191

For Enion, this is clearly an undesirable choice, but for Pullman it is desirable. Mary Malone plays a counsellor's role in her relationships with Will and Lyra, both in her explaining to Lyra what she knows about Dust and her resolving to help Will after they return to their world. She is an adult figure upon whom the children can rely to guide them through their adventure. The role she plays as a storyteller could also be considered a role as counsellor, as her stories help Will and Lyra to discover more about themselves and their sexuality, aiding their growth and development. Listening, Lyra "knew exactly what she meant, and half an hour earlier she would

\footnotetext{
190 Spyglass, 518.

191 “Zoas", II: 598-600.
} 
have had no idea at all. And inside her, that rich house with all its doors open and all its rooms lit stood waiting, quiet, expectant." ${ }^{192}$ Having gained an understanding of love from Mary Malone, Will and Lyra are able to fall in love themselves.

Blake and Pullman reject the notion of God the Father as he is presented in Paradise Lost. Pullman's description of the Authority recalls Blake's Nobodaddy, who is addressed in "To Nobodaddy" (c. 1791-2):

Why art thou silent and invisible,

Father of jealousy?

Why dost thou hide thyself in clouds

From every searching eye ${ }^{193}$

The Authority is similarly "silent and invisible", as Metatron does his work for him. He hides from those who wish to find him as he is weak and unable to fight. Barach reports to Lord Asriel that "[Metatron] intends to move the Authority secretly away from the Clouded Mountain, to a permanent citadel somewhere else, and turn the mountain into an engine of war." ${ }^{194}$ Like Nobodaddy, the Authority has been in the clouds, and Metatron intends him to remain hidden. Nobodaddy appears again in "Let the brothels of Paris be opened" where he states "To kill the people I am loth; / But if they rebel they must go to hell: / They shall have a priest and a passing bell." 195 Like Nobodaddy condemning those who rebel to Hell, the Authority established the gloomy land of the dead in the early ages. ${ }^{196}$ With the Authority aged and decrepit, "hideous cruelties [are] dealt out in the Authority's name"197 by the church. Nobodaddy is portrayed as a once cruel but now redundant God, a description which also applies to the Authority.

\footnotetext{
${ }^{192}$ Spyglass, 468.

${ }^{193}$ William Blake, “To Nobodaddy” (c.1791-2), 1-4.

${ }^{194}$ Spyglass, 63.

${ }^{195}$ William Blake, "Let the brothels of Paris be opened" (c.1791-2), 10-12.

${ }^{196}$ Spyglass, 35.

${ }^{197}$ Knife, 283.
} 
Pullman declares “I loved and revered William Blake's Songs of Innocence and of Experience, which as Blake said were written to show those contrary states of the human soul". ${ }^{198}$ Unsurprisingly, these poems are an influence on His Dark Materials. Pullman provides a link via the epigraphs at the beginning of the chapters in The Amber Spyglass. Of the ten Blakean quotations used, three are from Songs of Innocence and of Experience, and two of these are from "The Little Girl Lost" (c.1789). The immediate link between this poem and Pullman's work is that the girl's name is "Lyca", one letter away from "Lyra" (whom Pullman tellingly refers to as "a little girl, lost"199). The poem, and its companion "The Little Girl Found" (c.1789), have been interpreted as depicting either a sexual awakening or death. Pullman, in his apparent appropriation of it, interprets it to be the former. The epigraph to the first chapter of The Amber Spyglass is taken from a stanza of "The Little Girl Lost" which reads:

Sleeping Lyca lay

While the beasts of prey -

Come from cavern deep,

Viewed the maid asleep. ${ }^{200}$

Lions, leopards, and tigers play around her as she sleeps. The lion's licking of her neck and the lioness's undressing of her in the poem's concluding stanzas indicate that she is experiencing a sexual awakening. Lyra also experiences a sexual awakening sleeping under a tree. ${ }^{201}$

“The Little Girl Found" centres on Lyca's parents' search for their daughter. Not knowing where she is, they dream that she is "Famished, weeping, weak". ${ }^{202}$

\footnotetext{
198 "Folio Society Preface".

${ }^{199}$ Knife, 167.

${ }^{200}$ William Blake, "The Little Girl Lost" (c.1789), 33-36.

201 Spyglass, 472.

${ }^{202}$ Blake, "The Little Girl Found" (c.1789), 15. (Hereafter referred to as "Found".)
} 
They imagine her to be in a worse situation than she is. Though afraid meeting the lion, "their fears allay / When he licks their hands". ${ }^{203}$ At the poem's conclusion they look at Lyca sleeping and no longer "fear the wolvish howl / Nor fear the lion's growl." ${ }^{204}$ Lyca's parents realise that Lyca's experience had not been the terrible one they had imagined. Lyra's mother, Mrs Coulter, is cast in a similar role in The Amber Spyglass. In a reversal of events, it is she who causes Lyra's sleep, but like Lyca's parents she wants to protect Lyra from a perceived danger. She tells Will that she is keeping Lyra drugged and asleep because the church wants to kill her. ${ }^{205}$ Like Lyca's parents, however, she cannot keep Lyra from danger indefinitely.

The repression of (often sexual) joys and desires by institutionalised religion is a theme which arises in the Songs. "The Garden of Love" (c. 1794) epitomises this. The speaker, returning to the Garden where they once played, finds graves, tombstones, and a chapel with "thou shalt not" written over the door. The love and play which once occurred in the garden are now prohibited. Turning to the garden the speaker laments "priests in black gowns were walking their rounds, / And binding with briars my joys and desires." ${ }^{206}$ Pullman's priests and assorted religious figures also bind people's joys and desires. The church's severing of children from their daemons prevents the children from undergoing puberty, thereby preventing them from experiencing joys and desires. Asriel explains that there is a precedent for this:

"Do you know what the word castration means? It means removing the sexual organs of a boy so that he never develops the characteristics of a man. A castrato keeps his high treble voice all his life, which is why the Church allowed it: so useful in Church music., 207

\footnotetext{
203 “Found", 30-31.

204 “Found”, 51-52.

205 Spyglass, 147.

${ }^{206}$ William Blake, "The Garden of Love" (c.1794), 11-12.

${ }^{207}$ Lights, 374.
} 
Such a boy has also had his joys and desires bound by the Church.

Blake, in "A Little Girl Lost" (c. 1794), optimistically envisions a future where love is no longer considered a crime. The poem opens in an address to future readers:

Children of the future age,

Reading this indignant page,

Know that in a former time

Love, sweet love, was thought a crime. ${ }^{208}$

Pullman's trilogy, at its conclusion, is equally optimistic. Perhaps Will and Lyra are these "children of a future age". After the discovery that love is what stops Dust from escaping, and the realisation that this is a good thing, it is likely that love will no longer be thought of as a crime. Looking at Will and Lyra after they have fallen in love, Mary notes:

They would seem the true image of what human beings always could be, once they had come into their inheritance.

The Dust pouring down from the stars had found a living home again, and these children-no-longer-children, saturated with love, were the cause of it all. ${ }^{209}$

As Will, Lyra, and Mary return to their worlds one imagines that they will explain what they have learnt about Dust and love to others, and the future age that Blake speaks of may become a reality.

Pullman's "selective credo" obtained from Blake's work is evident in his own trilogy. He adopts and adapts for his own purposes Spectres and emanations, an aged and redundant God, and the theme of innocence and experience. Though Blake's poetry is a significant influence it is a piecemeal one as many Blakean aspects are absent in His Dark Materials.

\footnotetext{
${ }^{208}$ William Blake, c. 1794, “A Little Girl Lost”, 1-4.

${ }^{209}$ Spyglass, 497.
} 
Pullman clearly admires Heinrich von Kleist's essay “On the Marionette Theatre" (1810), and casts Kleist in the role of genius precursor whose skill he can only attempt to match. The essay was an influence on Pullman's series, and he notes in the preface to the Folio Society edition of His Dark Materials:

My story is much longer than the essay, but that is because I am much less of a genius than Kleist was; he managed to say in 2500 words or so what I could only cram into 1200 pages. $^{210}$

The 2500 words and 1200 pages each feature an encounter with a bear. Kleist's bear battles a human opponent in a fight similar to that between Iorek Byrnison and Iofur Raknison. Kleist's bear easily defeats his opponent:

'It wasn't merely that he parried my thrusts like the finest fencer in the world; when I feinted to deceive him he made no move at all. No human fencer could equal his perception in this respect. He stood upright, his paw raised ready for battle, his eye fixed on mine as if he could read my soul there, and when my thrusts were not meant seriously he did not move."211

Unfettered by human consciousness, the bear - who only knows how to be a bear triumphs over his human opponent who is focussing not only on his fighting but his astonishment at fighting a bear, the bear's posture and seriousness, and his own feinted moves. Iorek's fight is similar. Though Iorek is content as a bear, Iofur has "fallen" and desires to be human. Lyra appeals to this desire as she tricks him, pretending that she will be his daemon. Iorek and Kleist's bear cannot be deceived, because they retain their "bearness". Iorek tricks Iofur, faking a limp to lull him into a false sense of security before triumphing over him. It is remarked: "You could not

\footnotetext{
210 "Folio Society Preface".

${ }^{211}$ Heinrick von Kleist, 1810, "On the Marionette Theatre”, trans Idris Parry, http://www.southerncr ossreview.org/9/kleist.htm. (accessed 21 October 2009). (Hereafter referred to as "Theatre".)
} 
trick a bear, but, as Lyra had showed him, Iofur did not want to be a bear, he wanted to be a man; and Iorek was tricking him.",212

The similarity between the bears points towards a more significant resemblance between the texts: each engages with the theme of innocence and experience. (Iorek and Kleist's bear, innocent, win their fights while Iofur and the human, experienced through having "fallen", lose.) Kleist's essay opens with the observation of a puppet's movements, which the essayist claims are more graceful than any movements of the human body. The narrator, upon expressing disbelief, is told that he clearly has not "read the third chapter of the book of Genesis with sufficient attention." ${ }^{213}$ This chapter depicts the Fall of Adam and Eve and their subsequent expulsion from the Garden of Eden. They gain consciousness, and in doing so lose their natural grace. Pullman observes: "So far, so conventional. Grace and innocence are a paradise from which we are cast out, and all we can do is lament." ${ }^{\text {214 }}$ Kleist then swerves from the biblical account. With Paradise "locked and bolted" people must "go on and make the journey round the world to see if it is perhaps open somewhere at the back." ${ }^{, 215}$ The essay concludes:

"Grace appears most purely in that human form which either has no consciousness or an infinite consciousness. That is, in the puppet or in the god."

"Does that mean", I said in some bewilderment, "that we must eat again of the tree of knowledge in order to return to the state of innocence?"

"Of course", he said, "but that's the final chapter in the history of the world."216

Lyra's reading of the alethiometer illustrates Kleist's theory of grace. She initially reads the alethiometer intuitively by natural grace, explaining:

\footnotetext{
${ }^{212}$ Lights, 353.

213 "Theatre".

214 "Folio Society Preface".

215 "Theatre".

216 "Theatre".
} 
"I just let my mind go clear and then it's sort of like looking down into water. You got to let your eyes find the right level, because that's the only one that's in focus.",217

She demonstrates her reading with ease when Dr Lanselius asks "I wonder if I might ask to see you do it?"218 Later, having "fallen", she finds she can no longer read the alethiometer:

... she gazed at the symbols, once more she turned the wheels, but those invisible ladders of meaning down which she'd stepped with such ease and confidence just weren't there. She just didn't know what any of the symbols meant. ${ }^{219}$

In Kleist's essay humans can "eat again of the tree of knowledge" to return to a state of grace. Lyra can 'eat' again to regain her ability to read the alethiometer. What she once read by grace she may read again by knowledge. The Master of Jordan suggests that she "make the alethiometer the subject of [her] life's work, and set out to learn consciously what [she] could once do by intuition", ${ }^{220}$ studying the meanings of the symbols as they are recorded in books. She must journey around the world and enter in the back gates of the Garden.

Kleist's essay implies that there must be a second Fall to return humanity to a state of grace. Lyra's fall into consciousness is a second Fall for all humanity, as she is "Eve, again! Mother Eve!"221 Lyra and Will's fall into consciousness stops the escape of Dust, enabling everybody to similarly fall, as Dust endows humans with consciousness. The trilogy ends before it is known if 'eating of the tree of knowledge' does return humanity to a state of grace. However, Lyra's resolve to build the Republic of Heaven in the trilogy's final lines indicate that this is the case.

\footnotetext{
${ }^{217}$ Lights, 173-174.

${ }^{218}$ Lights, 174.

219 Spyglass, 518.

${ }^{220}$ Spyglass, 544-545.

${ }^{221}$ Knife, 328.
} 
Paradise - where Adam and Eve resided before the Fall - is attainable through a conscious effort to build it.

Pullman's appropriation of "On the Marionette Theatre" is interesting as he does not alter the theme, but applies it to his own depicted universe. The similarities are extremely mimetic but Pullman does not shy away from the influence, instead directing readers towards Kleist's essay remarking "I can hardly own up to [the influence] without drawing attention to that wonderful essay in the first place."222

Burton Hatlen, in an essay comparing Pullman's trilogy to The Lord of the Rings, The Chronicles of Narnia, and Paradise Lost, argues that His Dark Materials is a Neo-Romantic reading of Paradise Lost. He sees Pullman, like the Romantics before him, as “[regarding] Milton's God as an unjust and arbitrary tyrant, and ... Satan [as] the 'true hero' of Paradise Lost, a gallant Promethean rebel fighting on in a cause that he knows is doomed but still insists is just." ${ }^{223}$ This comparison provides some insight into the relationship between the texts - Pullman's Authority is unjust and tyrannical, and Lord Asriel wages war against him - but the connection has a greater level of sophistication. Pullman's reading of Paradise Lost can be seen to follow Harold Bloom's theory of misreading, as it swerves from and empties the poem of its original meaning, then completes it so that it has a new meaning.

Bloom's theory of a misreading has three parts, and each part consists of a limitation and a representation. The first pairing is of clinamen (a swerve from the original meaning) and tessera (the completion and antithesis of meaning). The

\footnotetext{
222 "Folio Society Preface".

${ }^{223}$ Burton Hatlen, "Pullman's His Dark Materials, a Challenge to the Fantasies of J. R. R. Tolkein and C. S. Lewis, with an Epilogue on Pullman's Neo-Romantic Reading of Paradise Lost". In His Dark Materials Illuminated: Critical Essays on Philip Pullman's Trilogy, edited by Millicent Lenz and Carole Scott, 75-94, (Detroit: Wayne State University Press, 2005), 86.
} 
misreading swerves from the original text, as a dialectical interplay of presence and absence withdraws meaning. The text's meaning is limited by what remains of the precursor, and represented by the resulting synecdoche where the remaining fragment of the original whole represents a new whole. The second part of misreading is the combination of kenosis (emptying the precursor text of meaning) and daemonisation (or the counter sublime). Kenosis limits the original text, emptying it of meaning through metonymy and displacement, and daemonisation presents a new meaning as a breakthrough to the counter-sublime is shown through images of highness and lowness. The final part of misreading is the combination of askesis (a movement of self purgation) and apophrades (the return of the dead), culminating in a return of lost voices and almost-abandoned meanings.

Presence and absence are significant in His Dark Materials' swerve from and completion of Paradise Lost. The later work retains the rebellion, Fall, and harrowing of Hell, but God and Satan (as the ultimate forces of good and evil) are notably absent. Pullman's God-figure, the Authority, has become irrelevant. Barach explains to Asriel that:

“... he has retired to a chamber of crystal deep within the Clouded Mountain, and ... he no longer runs the daily affairs of the kingdom. Instead he contemplates deeper mysteries. In his place, ruling on his behalf, there is an angel called Metatron." 224

In "the early ages" the Authority established the land of the dead. It is referred to as a "prison camp", ${ }^{225}$ and is where everybody goes after death, regardless of their actions or religious affiliation. The Authority, once tyrannical and later irrelevant, is greatly removed from the God of Paradise Lost who is purely good. Similarly, Satan - in His Dark Materials - is not the purely evil and malicious character that he is in

${ }^{224}$ Spyglass, 63.
225 Spyglass, 35. 
(an orthodox reading of) Paradise Lost. Pullman uses two characters to fulfil the Satanic role, Lord Asriel and Mary Malone. Asriel is the rebel Satan, and is neither good nor evil. Maureen Johnson notes that from the outset of Northern Lights two sides of Asriel are evident. Within moments of meeting Lyra he threatens to break her arm, and then calls the butler a "careless old fool". ${ }^{226}$ Johnson remarks "Really, this should not work. This man just strode into the story, insulted the help, and immediately started smacking around a child. I should dislike him. But I don’t."227 However, Asriel's presentation to the scholars of his discoveries about Dust indicate that he is doing some noble or important work, so the reader is able to forgive his earlier actions. Asriel later describes his mission:

"Somewhere out there is the origin of all the Dust, all the death, the sin, the misery, the destructiveness in the world. Human beings can't see anything without wanting to destroy it, Lyra. That's original sin. And I'm going to destroy it. Death is going to die."228

This is surely a noble aim - without death, sin, and misery humans would be able to live a happier existence. However, the "evil" side to Asriel is again evident when he kills Roger as a part of this mission. The two sides of Asriel continue to coexist throughout the trilogy.

Mary Malone is Satan the tempter. She is instructed by Dust to "play the serpent", ${ }^{229}$ which she does in the role of storyteller. Her story tempts Will and Lyra to discover their own sexuality and love for one another, which results in a second Fall. However, she does not undertake this role out of malice, but out of a "weight of responsibility", ${ }^{230}$ and she can hardly be considered an evil character. She acts as a

\footnotetext{
${ }^{226}$ Lights, 15.

${ }^{227}$ Maureen Johnson, "Hot Sex and Horrific Parenting in His Dark Materials". In The World of the Golden Compass: The Otherworldly Ride Continues, edited by Scott Westerfeld, 43-53, (USA:

BenBella Books, 2007), 45.

${ }^{228}$ Lights, 377.

${ }^{229}$ Knife, 261.

${ }^{230}$ Spyglass, 463.
} 
guide and protector for Will and Lyra, showing Lyra how her computer is able to talk to Dust, and offering Will both care for his mother and a home.

Left with a powerless God, a caring serpent, and Satan on a noble quest, the subsequent representation of the church completes the meaning of the precursor text which was broken in His Dark Materials. God is not divine, Satan is not evil, and the Fall was not bad, so religion becomes a construct, with a suppressive and controlling church. All of the religious characters are negatively portrayed. The tellingly named Father MacPhail orders Lyra's assassination, and Father Gomez is proud to be chosen as the assassin. Father Heist (whose name is also a play on words) is the most positively portrayed religious character, yet he is uninterested in Lyra's spiritual wellbeing, deeming her spiritually unpromising. Mrs Coulter, though redeemed at the end of the series, uses the church to gain power in the material world. Asriel explains to Lyra:

'Naturally she couldn't take the route a man could have taken - priesthood and so on - it had to be unorthodox; she had to set up her own order, her own channels of influence, and work through that. It was a good move to specialize in Dust. Everyone was frightened of it; no one knew what to do; and when she offered to direct an investigation, the Magisterium was so relieved that they backed her with money and resources of all kinds."231

Surprisingly, she is not unlike religious leaders described in Paradise Lost. Milton remarks that after the death of the apostles:

Wolves shall succeed for teachers, grievous Wolves,

Who all the sacred mysteries of Heav'n

To thir own vile advantages shall turne

Of lucre and ambition, and the truth

With superstitions and traditions taint,

Left onely in those written Records pure,

${ }^{231}$ Lights, 374. 
Though not but by the Spirit understood.

Then shall they seek to avail themselves of names,

Places and titles, and with these to joine

Secular power, though feigning still to act

By spiritual ... ${ }^{232}$

The church in Pullman's trilogy also taints the truth "with superstitions and traditions". Barach reveals to Will that "Everything about [the land of the dead] is secret. Even the churches don't know; they tell their believers that they'll live in Heaven, but that's a lie."233 However, the church in Milton's poem was not originally like this, as it was based on truth and a true God. Without this foundation the church in His Dark Materials was always malevolent, and the meaning of each text is significantly different because of the different foundation of the church.

In the second part of his misreading, Pullman empties Milton's notion of God. God loses his status as creator, and becomes merely the first angel created - a fraud who "told those who came after him that he had created them." 234 This, in turn, empties God of his right to supremacy over creation. It also strips him of his perpetual existence - he did not exist before his creation, and he does not exist after his "death" in The Amber Spyglass. The undoing of Milton's notion of "God" also empties "sin" of its meaning. As disobedience towards God, sin is a grave transgression. Without this God to transgress against, sin takes on a less severe meaning. Pullman, however, empties it further. Eve's sin is disobedience. Knowing that God has forbidden her to eat from the Tree of Knowledge, she does. Lyra's sin is not disobedience. Jonathan Townsend, in considering the series as a reshaping of Paradise Lost, rightly states that Lyra's sin is sex. She falls because she becomes

\footnotetext{
${ }^{232}$ Paradise Lost, XII: 508-518.

233 Spyglass, 35.

${ }^{234}$ Spyglass, 33-34.
} 
aware of her sexuality. Townsend adds that Milton emphasises the sexual pleasure of Adam and Eve, and that "The rehabilitation of sexual enjoyment is not really one of the things that correcting Milton [as part of a reshaping of Paradise Lost] needs to be about."235 "Correcting” Milton, however, is not Pullman's intention. "Sin”, when synonymous with sex, is not a bad thing in His Dark Materials. Will and Lyra's discovery of their love for one another stops the escape of Dust. Sex is likewise celebrated in Milton's work. The passage beginning "This said unanimous, and other Rites / Observing none"236 describes Adam and Eve not refusing one another sex, as it is something God has ordained and made pure. Pullman treats sex with the same sensuousness that Milton does, but by associating it with the Fall and original sin he elevates it to a higher status. This forms part of the counter-sublime which is created through the revisionary ratio daemonisation. The sublime Paradise Lost engages with the "high" themes of God and original sin. His Dark Materials, in turn, becomes counter-sublime and deals with "low" themes - an angel who pretends to be God, and sex. The counter-sublime is also created by Pullman's casting of Lyra and Will as the heroes. Orthodox Christianity dictates that God should be the hero of Paradise Lost while the poem's focalisation suggests that it could be Satan. But Pullman's sympathies lie with Eve: “I thought wasn't it a good thing that Eve did, isn't curiosity a valuable quality? Shouldn't she be praised for risking this?"237 It is unsurprising, then, that she becomes the hero in Pullman's own work. The God and Satan of His Dark Materials ultimately perish - the Authority dissolves into the air, Asriel falls into the abyss, and Mary Malone fulfils her satanic purpose as serpent. Will and Lyra, after their adventure, return to their own worlds intending to build the

\footnotetext{
${ }^{235}$ John Rowe Townsend, "Paradise Reshaped", The Horn Book Magazine 78.4 (2002): 415-421, http://find.galegroup.com.helicon.vuw.ac.nz. (accessed 14 September 2009).

${ }^{236}$ Paradise Lost, IV: 736-747.

237 "Faith and Fantasy, Encounter, ABC (Australia, 24 March 2002), http://www.abc.net.au/rn/relig/ enc/stories/s510312.htm. (accessed 13 February 2010).
} 
Republic of Heaven. In this sense they, as humans, are the heroes - rather than either of the supernatural characters.

In the final part of its misreading, His Dark Materials returns to the passage in Paradise Lost from which the series takes its title:

... Into this wilde Abyss,

The Womb of nature and perhaps her Grave,

Of neither Sea, nor Shore, nor Air, nor Fire,

But in all these in thir pregnant causes mixt

Confus'dly, and which thus must ever fight,

Unless th’ Almighty Maker them ordain

His dark materials to create more Worlds,

Into this wild Abyss the warie fiend

Stood on the brink of Hell and look'd a while,

Pondering his Voyage ${ }^{238}$

This is, as Hatlen observes, a moment of maximum potentiality. Sea, land, air, and fire do not yet exist. In Chaos, which the passage describes, "light and darkness, male and female ... have not yet been sorted out and classified as 'good' or 'evil'. Out of this clash of opposites ... many worlds ... may come." ${ }^{239}$ His Dark Materials represents a return to this abandoned moment of infinite possibility, and Pullman's text develops these potentialities differently to Milton's. Milton's God creates earth, a world for humans to live in, while Pullman constructs his multiverse. "Good" and “evil" become associated with God and Satan in Milton's work, but the distinction is blurred in Pullman's work as everyone has the potential for both good and evil. The realm of great potentiality is thrown open again at the conclusion of the trilogy.

${ }^{238}$ Paradise Lost, II: 910-919.

${ }^{239}$ Burton Hatlen, “Pullman's His Dark Materials, a challenge to the Fantasies of J. R. R. Tolkein and C. S. Lewis, with an Epilogue on Pullman's Neo-Romantic Reading of Paradise Lost". In His Dark Materials Illuminated: Critical Essays on Philip Pullman's Trilogy, edited by Millicent Lenz and Carole Scott, 75-94, (Detroit: Wayne State University Press, 2005), 87. 
Asriel and the Authority have both perished, seemingly leaving their forces in an unresolved battle. It is not stated which side ultimately wins the war on Heaven, and as the final book ends Lyra resolves to build the Republic of Heaven. The reader is left to imagine the future.

Pullman performs a very careful and deliberate misreading of Paradise Lost and is ultimately successful in telling a story which, while derived from Milton's epic, is original. By breaking the meaning of the original text and refocusing it, His Dark Materials unsettles the foundations of the precursor work and moves towards a different conclusion.

Similarities between His Dark Materials and C. S. Lewis's Narnia, most notably the wardrobe motif in each, indicate that Lewis's series was an influence on Pullman. Pullman, however, does not acknowledge this influence and is coy when asked about $\mathrm{it}^{240}$ - likely because of an embarrassment that his work is similar to the series he loathes. In his effort to present a different ideology to that in Narnia, he inadvertently makes his work more like Lewis's, as each author forcefully pushes their ideology. Ned Vizzini, in an essay discussing the tropes and techniques of each work, summarises each author's approach:

Narnia, when explicitly Christian, falls into sappy, obvious imagery: tear-shedding and aggrandized speeches on the part of Aslan, whose death on the stone table is exaggerated to the point of treacle. Meanwhile, Pullman has a difficult job with HDM as he has no godlike figure to lead him through his didacticism. Instead he must make his statements of purpose blatant, risking breaks in the action that can bludgeon the reader - there are only so many

\footnotetext{
240 “An Interview with Philip Pullman", More Intelligent Life, 3 December 2007. http://www.morein telligentlife.com/node/697 (accessed 20 March 2010). Pullman, asked whether his series is a rival to that of Tolkein or Lewis, answered "If I was doing it at all, I was arguing with Narnia", implying that any influence has not been intentional.
} 
times that characters in The Amber Spyglass can declare that there is no God and Christianity is a mistake. ${ }^{241}$

The forceful ideology in His Dark Materials is, in part, a result of a deliberate misreading of and writing back against Narnia. Pullman alludes to Lewis's series through Lyra and Will's experiences, and then writes back correctively against elements of the series which he sees as flawed. This misreading is less sophisticated than his misreading of Paradise Lost. Often his objection to Lewis's work is so strong that he becomes blinded to the actual text and responds to assumptions about the series, which detracts from the new story he is telling. The misreading does not "come full circle" as with Paradise Lost, reaching the final stage in which the later text returns the lost voices and almost-abandoned meanings of the precursor text. Instead, the misreading of Narnia occurs largely within Bloom's first pairing of clinamen and tessera and the second pairing of kenosis and daemonisation.

Pullman alludes to Narnia through the experiences of Lyra and Will, directing readers to the resemblance between the two works. In the case of each character, the sum of a number of small similarities indicates Narnia's influence on His Dark Materials. Within the first few pages of Northern Lights Lyra hides in a wardrobe in the Retiring Room, and what she overhears while there marks the start of her adventure. The adventures in Narnia begin, of course, when Lucy steps into a wardrobe. Both Lyra and the Pevensie children employ the wardrobe as a hiding place, and make use of the fur garments they find there. Lyra finds "that the wardrobe was bigger than she'd thought", ${ }^{242}$ and the Pevensie children discover that their wardrobe houses an entire country. There is also a verbal similarity in the way

\footnotetext{
${ }^{241}$ Ned Vizzini, "God is in the Stories: His Dark Materials vs. Narnia". In The World of the Golden Compass: The Otherworldy Ride Continues, edited by Scott Westerfeld, 143-153, (USA: BenBella Books, 2007), 151.

${ }^{242}$ Lights, 8.
} 
that the characters leave the wardrobe - they 'tumble'. In The Lion, the Witch, and the Wardrobe "they all came tumbling out of a wardrobe door into the empty room". ${ }^{243}$ Lyra, seeing Asriel about to drink a poisoned beverage, "tumbled out of the wardrobe and scrambled up to snatch the glass from his hand."244

Will's experiences with the subtle knife allude to Narnia, strengthening the connection between the two series. Like Lucy, he discovers a new world underneath a streetlight. It is night-time in each case, and as Narnia is difficult to find - the wardrobe is not always open to the other country - the city Will finds is "nearly invisible". ${ }^{245}$ Lucy's return journey to the lamppost after meeting and having tea with Mr Tumnus is a dangerous one as the pair attempt to avoid the White Witch's spies, and Will discovered a window into the new world while looking to hide from the police and men chasing him. It is later revealed that the window Will discovered was cut by the subtle knife, an instrument capable of cutting holes in the thin fabric which separates the universes and which allows the bearer to "cut an opening out of [the] world altogether". ${ }^{246}$ As the bearer, there are many possible worlds for Will to enter. This is reminiscent of "the Wood between the Worlds" in Lewis's The Magician's Nephew (1955). The Wood is full of pools, and by jumping into any one of them one may enter a different world. Digory tells Polly that "I think we can get out of this place into jolly well anywhere!" 247 The Wood, like the knife, represents the possibility of moving between worlds.

Pullman's appropriation of these aspects of Narnia is certainly intentional and perhaps parodic, as if they are intended to emphasise the differences between

\footnotetext{
${ }^{243}$ C. S. Lewis, The Lion, the Witch, and the Wardrobe, (1950; repr., London: HarperCollins, 2001), 202. (Hereafter referred to as Wardrobe.)

${ }^{244}$ Lights, 13.

${ }^{245}$ Knife, 15.

${ }^{246}$ Knife, 190.

${ }^{247}$ C. S. Lewis, The Magician's Nephew (1955; repr., London: HarperCollins, 2001), 47.
} 
Narnia and His Dark Materials. His own series, however, bears another startling resemblance to Lewis's, though this is one which is seemingly unintentional. Pullman, as Tristan Clark observes, shows "a very Lewis-like desire for everything to be in its proper place". ${ }^{248}$ This is particularly evident in the depiction of bears. Iofur Raknison's desire to be human is clearly something unnatural and wrong. It causes him to be "restless", ${ }^{249}$ and his courtiers "weren't sure what they were."250 They lack the certainty that Iorek Byrnison has - and as he is a "true bear" he triumphs over Iofur in battle. Similarly, in Narnia the White Witch bases her claim to be Queen on the pretence that she is human. Mr Beaver warns that "there's no two views about things that look like humans and aren't ... when you meet anything that's going to be human and isn't yet, or used to be human once and isn't now, or ought to be human and isn't, you keep your eyes on it and feel for your hatchet." 251 Both authors display a liking for boundaries, which is odd, considering Pullman's criticism of Lewis's attempt to prevent his child characters from growing up. It is likely that this particular similarity between the books is one Pullman would not want recognised.

Though this resemblance between Pullman's bears and Lewis's characters appears unintentional, Pullman seems to make deliberate connections between Iorek and Aslan. Each is a large and powerful talking animal who acts as a guide for the main characters. Iorek is the king of the bears at Svalbard and Aslan is "the king ... the Lord of the whole wood". 252 The difference between them is that Aslan, representative of God, has a lofty and spiritual status, while Iorek is a secularised

${ }^{248}$ Tristan Clark, "The Christian, the Atheist, and the Critics: An Analysis of Philip Pullman's His Dark Materials in Relation to C. S. Lewis's Narnia." Honours research essay, Victoria University of Wellington, 2007, 12.

${ }^{249}$ Lights, 349 .

${ }^{250}$ Lights, 345 .

${ }^{251}$ Wardrobe, 91.

${ }^{252}$ Wardrobe, 87. 
flesh and blood character. This difference is telling, as Pullman has brought about a reduction of status and emptied the original character of meaning. It indicates the challenge that His Dark Materials will present to Narnia, as in fact Pullman's use of the wardrobe does. Lyra, who "darted to the oak wardrobe, opened it, and hid inside, pulling the door shut just as the Steward entered", ${ }^{253}$ had clearly not heeded the advice given three times in The Lion, the Witch, and the Wardrobe. Lucy and Peter each left the door open after entering the wardrobe, ${ }^{254}$ and the narrator emphasises that "you should never, never shut yourself up in a wardrobe." ${ }^{, 255}$ Edmund, however, enters the wardrobe and shuts the door "forgetting what a very foolish thing this is to do. ${ }^{256}$ Lyra is foolish by Narnian standards, but Pullman does not consider her so. This is only a small challenge to Lewis's series, but it signifies the continuing opposition His Dark Materials will present to Narnia. The connection between Iorek and Aslan signifies how His Dark Materials will oppose Lewis's series - by correcting the meaning of the original text, swerving from it and replacing it.

Pullman has been extremely vocal in his criticism of Narnia, perhaps most notably in his 1998 article "The Darkside of Narnia". Here, he attacks Lewis's work as displaying "misogyny ... racism ... [a] sado-masochistic relish for violence", being "propaganda in the service of a life-hating ideology" and "one of the most ugly and poisonous things [he had] ever read. ${ }^{, 257}$ As well as attacking the books, he attacks their author, deeming Lewis a "tweedy medievalist" who didn't like women or sexuality and "was frightened and appalled at the notion of wanting to grow up."258 The article highlights aspects of Narnia which Pullman both criticises

\footnotetext{
${ }^{253}$ Lights, 7.

${ }^{254}$ Wardrobe, 13, 61

${ }^{255}$ Wardrobe, 61.

${ }^{256}$ Wardrobe, 34.

257 "Darkside".

258 "Darkside".
} 
elsewhere, and treats differently in his own work. His criticisms vary in their legitimacy. Seemingly appalled that Susan has been "sent to hell",259 because she has grown up and become aware of her sexuality, Pullman has not recognised that Susan - unlike the rest of her family - does not die in The Last Battle. Admittedly, she is unceremoniously dismissed in the final book, ${ }^{260}$ but she was not on the train which crashed, and Lewis confirmed in a 1957 letter that "the books don't tell us what happened to Susan. She is left alive in this world ... perhaps she will get to Aslan's country in the end ..."261 Pullman's claim that Lewis was fearful of sexuality is one that is more valid, as representation of sexuality is absent in Narnia, but Susan's “exclusion" from Aslan's Country does not appear to be because she grew up. For Lewis, growing up was a process of "adding on". Lewis says in his essay "On Three Ways of Writing for Children" that as an adult:

I now like hock, which I am sure I should not have liked as a child. But I still like lemonsquash. I call this growth or development because I have been enriched: where I formerly had only one pleasure, I now have two. But if I had to lose the taste for lemon-squash before I acquired the taste for hock, that would not have been growth but simply change. ${ }^{262}$

Susan has changed, not grown up. Jill says that Susan is "interested in nothing nowadays except nylons and lipstick and invitations". ${ }^{263}$ Presumably Susan could be interested in nylons and lipstick and believe in Narnia, but by considering it a "funny game" 264 she no longer believes in Aslan, and by proxy God. Pullman's belief that Susan has been condemned because she has grown up and become aware of her

\footnotetext{
${ }^{259}$ John Ezard, "Narnia Books Attacked as Racist and Sexist", The Guardian 3 June 2002, http://www.guardian.co.uk/uk2002/jun/03/gender.hayfestival/2002. (accessed 14 February 2010). ${ }^{260}$ As the characters are discussing Susan, Peter says "Well, don't let's talk about that now", and suggests that they all taste some fruit instead. C. S. Lewis, The Last Battle (1956; repr., London: HarperCollins, 2001), 168. (Hereafter referred to as Battle.)

${ }^{261}$ C. S. Lewis, 22 January 1957, "Dear Martin”. In Letters to Children, (New York: MacMillan, 1985), 67.

${ }^{262}$ C. S. Lewis, "On Three Ways of Writing for Children", 1966. In Of This and Other Worlds, edited by Walter Hooper, 56-70, (London: Collins, 1982), 60.

${ }^{263}$ Battle, 168. (Emphasis added.)

${ }^{264}$ Battle, 168.
} 
sexuality is tenuous, as her disbelief in Aslan is a far more likely reason for her to be excluded from salvation.

The "life-hating ideology" Pullman refers to is seen in the death of the children at the conclusion of the series. For Pullman, it is an inappropriate ending rather, the children should have been allowed to grow up in their own world and use what they had learnt in Narnia to help people. He deems Lewis's ending "ghastly and "a horrible message". ${ }^{265}$ Lewis, however, would see this as a fitting end to his series. The Narnia books show an overview of Christian theology, from the creation depicted in The Magician's Nephew to the Armageddon of The Last Battle. The characters' deaths and entry into Aslan's Country (the Narnian equivalent of Heaven) is in keeping with this ideology. Because Pullman himself does not ascribe to this world view he considers it horrible, but it is not so when situated within the terms Lewis establishes in his series.

Further to his claim that Narnia promotes a life-hating ideology, Pullman contends that the series portrays "a state of mind which, unless we're careful, can lead to a thoroughgoing hatred of the physical world." ${ }^{266}$ Lewis's series ends with the majority of the cast of human characters dying in a train crash, and finding themselves in Aslan's Country, the Narnian equivalent of Heaven. There is no "Narnia" for them to return to, and this is explained by Digory and Aslan. It had only been a shadow or copy of the real thing, and, having served its purpose, was destroyed in the chapter entitled "Night Falls on Narnia". ${ }^{267}$ There is no mention of their world (England), though it presumably still exists. For Pullman, this is an outrageous conclusion for the story to reach. Not only do the children not return to

\footnotetext{
${ }^{265}$ Susan Roberts, “A Dark Agenda?” Surefish November 2002, http://www.surefish.co.uk/culture/f eatures/pullman_interview.htm. (accessed 13 February 2010).

${ }^{266}$ Philip Pullman, "The Republic of Heaven", Horn Book, November 2001, www.hbook.com/m agazine/articles/2001/nov01_pullman.asp. (accessed 16 September 2009).

${ }^{267}$ Battle, 184-197.
} 
their own world to share what they have learnt for the benefit of others, but the physical world has been discarded in favour of a spiritual world. Because Narnia takes a Christian viewpoint, the spiritual is more important (or more lasting, perhaps) than the physical. The series does not, however, display the "hatred" of the physical that Pullman claims. Though they are happy to be in the "true" Narnia, Lucy, Jill, Digory, and Tirian mourn the Narnia they have known, Lucy remarking to Peter, “Don't try to stop me ... I am sure Aslan would not. I am sure it is not wrong to mourn for Narnia."268 Lewis's supposed hatred of the physical world is countered too with the emphasis he places on food in the Narnia books, often describing it with gusto and in elaborate detail. ${ }^{269}$

Harold Bloom writes of strong poets wanting to surpass or usurp their embarrassing ancestors. Lewis is clearly such an ancestor for Pullman embarrassingly potent and present. ${ }^{270}$ Lewis's influence on Pullman is shown, aside from the connections already discussed, through Narnia's absence and correction in His Dark Materials. William Gray contends that the first pair of Bloom's revisionary ratios - clinamen and tessera - apply most readily to Pullman's relationship with Lewis. ${ }^{271}$ In this pairing he uses presence and absence to withdraw meaning from, and to swerve from, Lewis's text. The replacement of what is absent completes the meaning. The substitution of the land of the dead in His Dark Materials for Aslan's Country is an example of this. The worldview of the text changes, as the spiritual afterlife becomes a horrific rather than wonderful place. The second pairing of revisionary ratios, kenosis and daemonisation, also features in the relationship, albeit

\footnotetext{
${ }^{268}$ Battle, 195.

${ }^{269}$ An example is the dinner the Pevensie children have with the Beavers. Wardrobe, 83.

${ }^{270}$ Anxiety, 20.

${ }^{271}$ William Gray, "Pullman, Lewis, MacDonald, and the Anxiety of Influence", Mythlore SpringSummer 2007, http://findarticles.com/p/articles/mi_m0OON/is_3-4_25/ai_n27253238/. (accessed 5 August 2009).
} 
to a lesser extent. Pullman empties elements to undo their meaning, and replaces "high" images with "low" ones to orchestrate a breakthrough to the counter-sublime. Iorek, as a reconstruction of Aslan, is an example of this. He is emptied of his Godlike status and becomes a flesh and blood animal. Because he still fulfils Aslan's role as a strong and powerful guide, he becomes an aspect of the counter-sublime - the "low" animal taking place of the "high" God.

In His Dark Materials Will and Lyra - unlike the children in Narnia - are allowed to grow up and discover their sexuality. Their growing up is seen through comments Lyra makes to and about Pan, as a person's daemon ceasing to change form signifies the person's growing up. As the series begins, Lyra feels she will never grow up and remarks "I want Pantalaimon to be able to change forever." 272 In the next book, she says wistfully, "I'm changing, I think, Pan." ${ }^{, 273}$ As the third and final book concludes, Lyra is content knowing that Pan will not change much anymore:

"It's funny", she said, “you remember when we were younger and I didn't want you to stop changing at all ... Well, I wouldn’t mind so much now."274

Her growing up is portrayed as a natural occurrence. Pullman also welcomes and celebrates the onset of sexuality in Will and Lyra, and the way it changes their relationship. Lyra's response to Mary Malone's story is one of sexual awakening. She "felt something strange happen to her body" and "the sensation continued, and deepened, and changed, as more parts of her body found themselves affected too."275 Will and Lyra's falling in love is portrayed in an erotic manner. Lyra lifts a small red fruit to his mouth. Their lips touch, and "before they knew how it happened, they

${ }^{272}$ Lights, 167

${ }^{273}$ Knife, 270.

${ }^{274}$ Spyglass, 527.

${ }^{275}$ Spyglass, 467-468. 
were clinging together, blindly pressing their faces towards each other." ${ }^{276}$ Lyra tells Will that she loves him, and he responds by "kissing her hot face over and over again, drinking in with adoration the scent of her body and her warm honey-fragrant hair and her sweet moist mouth ..."277 While Pullman feels that Susan's growing awareness of her sexuality condemns her, Lyra and Will's awareness of their sexuality saves rather than condemns. Mary Malone watches the pair through the amber spyglass and sees that "the Dust pouring down from the stars had found a living home again, and these children-no-longer-children, saturated with love, were the cause of it all." 278 This benefits all of humanity, as well as other races such as the mulefa, presenting the embracement of sexuality as productive and positive.

Pullman's depiction of growing up and sexuality is a swerve from Lewis's depiction (or lack of depiction) of the same subject. Pullman brings this aspect to what he believes is its natural completion - the conclusion that an adolescent's awareness of their sexuality is a natural part of their growing up. The elevation of sexuality in his work contributes to the text's breakthrough to the counter-sublime, as previously discussed in regard to Paradise Lost.

Pullman dislikes the ending of the Narnia series and bluntly emphasises in His Dark Materials how the conclusion of his story is different. Will and Lyra live out the rest of their lives in their own worlds, using what they have learnt to help people. At the conclusion of The Amber Spyglass, Will and Lyra learn that every opening made by the subtle knife must be closed, and that people cannot survive for long in a world other than their own. In a cruel plot twist they discover that one window can be left open, but decide that it must be left open for the dead. By returning Will and Lyra to their own worlds, Pullman allows two worlds to benefit

\footnotetext{
276 Spyglass, 492.

277 Spyglass, 492.

278 Spyglass, 497.
} 
from their experiences. Pullman makes it clear that this is a more fitting ending than frivolously whisking the children away to Heaven, as Will and Lyra insist "we have to live in our own worlds", ${ }^{279}$ "we shouldn't live as if [the Kingdom of Heaven] mattered more than life in this world", and "we've got to ... work hard, all of us, in our different worlds". ${ }^{280}$ Pullman has swerved from and completed the original text, bringing it to what he considers a more appropriate conclusion. Because he believes that the physical world is all that exists, he sees it fitting that his characters live out their lives in their own physical worlds, working to make them good and worthwhile places to live. Heaven is something that the characters must create themselves, in the physical world. The differences between the texts indicate the authors' different ideologies.

Pullman also presents two views of the afterlife to rival Lewis's. The land of the dead is a horrific imitation of Aslan's Country. It is "a place of nothing. The good [go there] as well as the wicked, and all of [them] languish in this gloom for ever, with no hope of freedom, or joy, or sleep or rest or peace." ${ }^{281}$ The land of the dead is obviously intended to mirror Aslan's Country. Each is a "spiritual" realm where people reside eternally after death. The difference between them is, of course, that Aslan's Country is wonderful while the land of the dead is horrible. In Narnia Aslan's Country is "more real and more beautiful"282 than Narnia, which is "a shadow or a copy of the real". ${ }^{283}$ The land of the dead, in turn, is a shadow of the physical world. It is an endless, misty plain, dim and gloomy, where ghosts wander aimlessly. ${ }^{284}$ People still exist after death, but as ghosts they are pale imitations of

\footnotetext{
279 Spyglass, 516.

280 Spyglass, 548.

281 Spyglass, 336.

${ }^{282}$ Battle, 220

${ }^{283}$ Battle, 208

${ }^{284}$ Spyglass, 309-310.
} 
the character they were when living. This difference illustrates Pullman's swerve from Lewis, as he denotes a spiritual existence after death as undesirable. In his own series it is preferable to become a part of the physical world after death. Lyra explains:

"All the particles that make you up will loosen and float away, just like your daemons did ... all the atoms that were them, they've gone into the air and the wind and the trees and the earth and all the living things ... And that's exactly what'll happen to you ... you'll be out in the open, part of everything alive again., 285

Though people lose the particular identity they had when they were alive, they continue to exist as a part of the physical world. This is gruesomely illustrated in Iorek's devouring of Lee Scoresby's body in what might be taken as a grisly version of a secular Eucharist. Iorek leaves the remains of the body so that "soon it would be nourishing a dozen different kinds of life." 286 Lee continues to exist as a part of his friend and other forms of life. Lisa Scally comments that this recalls Ruta Skadi's earlier musings: ${ }^{287}$

She rejoiced in her blood and flesh ... and in the earth below her and the lives of every creature, plant and animal both; and she delighted in being of the same substance as them, and in knowing that when she died her flesh would nourish other lives as they had nourished her. ${ }^{288}$

This difference between the texts is both an instance of tessera and of daemonisation. Pullman correctively completes the text's meaning, describing an alternate post-mortem existence. As an instance of daemonisation, his work is counter-sublime. In Lewis's work the spiritual is considered "high" and the physical "low". In Pullman's work the physical replaces the spiritual, as the characters -

\footnotetext{
285 Spyglass, 335.

286 Spyglass, 45.

${ }^{287}$ Lisa Scally, "Miraculous Bridges: Crossing Genre Boundaries via His Dark Materials", PhD thesis, Victoria University of Wellington, 2004, 127.

${ }^{288}$ Knife, 148.
} 
rather than going to Heaven after death - must build the Republic of Heaven in the physical world while they are alive.

Pullman observes that "The highest virtue - we have it on the authority of the New Testament itself - is love, and yet you find no trace of that in the [Narnia] books. ${ }^{289}$ Interestingly, here, rather than criticising Lewis for including Christian content in the Narnia series Pullman is criticising him for excluding it. But he overlooks Aslan's act of love as he dies in Edmund's place, as Christianity declares "No one has greater love than this, to lay down one's life for one's friends." ${ }^{290}$ Lewis would have considered himself to have included the greatest possible love in his series. Aslan's sacrifice, however, serves more of an allusive purpose than a plot purpose, included because it marks Aslan as a Christ-figure rather than because it is an act of love. In this sense, Pullman's criticism is well founded. Love plays a much greater role in His Dark Materials than it does in Narnia. Tristan Clark comments that love motivates many people to help Lyra, and cites the Master of Jordan, Iorek, and Lee Scoresby as examples. ${ }^{291}$ Lyra, however, is not the only character who is helped by acts of love. Agape (compassionate love) often drives the plot of His Dark Materials and can be seen throughout the trilogy. Lyra heads north to free her friend Roger, who has been captured by the General Oblation Board, in an act of agape. When she first discovers that he is missing her philia, (or friendship love) for him is evident as she shouts inconsolably at Bernie the pastrycook. The Subtle Knife sees Will fighting to attain the knife so he can help Lyra reclaim her alethiometer. This is

\footnotetext{
289 "Pullman Attacks Narnia Film Plans", BBC, 16 October 2005, http://news.bbc.co.uk/2/hi/ente rtainment/4347226.stm. (accessed 23 November 2009).

${ }^{290}$ John 15.13 (New Revised Standard Version)

${ }^{291}$ Tristan Clark, "The Christian, the Atheist, and the Critics: An analysis of Philip Pullman's His Dark Materials in relation to C. S. Lewis's Narnia." Honours research essay, Victoria University of Wellington, 2007, 6-7.
} 
clearly intended to benefit Lyra, not himself. Learning that he has become the bearer of the knife after winning the fight Will protests:

"But I - we only came here because - there was a man who stole something of Lyra's, and he wanted the knife, and he said if we brought him that, then he'd ...,292

Will and Lyra "kill" "God" out of compassion in The Amber Spyglass. Discovering the Authority in a crystal container, Lyra's compassion is evident as she calls him "poor thing", ${ }^{293}$ wants to comfort him, and wants to let him out to end his suffering. Will likewise shows compassion, cutting through the crystal and helping him out, saying “it's all right ... come on, we won't hurt you." ${ }^{294}$ Released from the crystal, the Authority dissolves into the air.

Donna Frietas and Jason King surmise that it is a "higher love" for all of creation that makes Will and Lyra sacrifice their own erotic love at the conclusion of the trilogy so that love may flourish among others in the future. ${ }^{295}$ Having discovered the erotic love they feel for each other, they - out of an act of agape sacrifice it, returning to their worlds alone. Allowed to leave one window open between worlds, they think first of leaving one open between their worlds, but feel too much compassion towards those trapped in the land of the dead to allow them to remain there. Had they kept two windows open Dust would have continued to escape (as people can renew only enough Dust to replace the amount which is lost through one window ${ }^{296}$ ), and humans would not be endowed with the consciousness that allows them to discover their sexuality and fall in love as Lyra and Will had.

Additionally, love has a transformational power in His Dark Materials which is shown through Mrs Coulter's love for Lyra. Metatron assesses her character in The

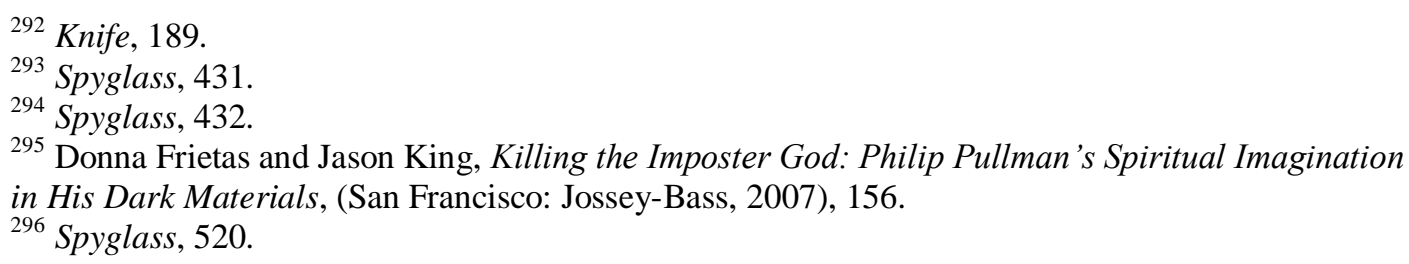


Amber Spyglass, searching her body, ghost, and daemon, and finds "corruption and envy and lust for power. Cruelty and coldness. A vicious probing curiosity. Pure, poisonous, toxic malice." However, this "cess-pit of moral filth" who has never performed an act of kindness or compassion which did not benefit her ${ }^{297}$ does develop a love for her daughter. She says:

"I love Lyra. Where did this love come from? I don't know; it came to me like a thief in the night, and now I love her so much my heart is bursting with it ... the mustard-seed [of love] had taken root and was growing, and the little green shoot was splitting my heart wide open $\ldots, 298$

This love causes her to sacrifice herself, as she and Asriel perish dragging Metatron down into the abyss. They do this for Lyra so she can live and grow up. Her love for Lyra redeems Mrs Coulter - an action which, for Lewis, is only possible through Christ. The biblical language Pullman uses casts love in the role of saviour instead. In the Bible it is the day of the Lord, or the second coming of Christ, which comes "like a thief in the night". ${ }^{299}$ The description of love as a "mustard seed" alludes to Jesus' statement that someone with faith the size of a mustard seed is able to move mountains $^{300}-$ it is small but powerful. In using biblical language Pullman elevates love - his world has no deity to redeem people, but love can.

Pullman's treatment of the theme of love, as a response to Narnia, does not fit so readily with Bloom's theory of influence. Rather than emptying it of meaning (as he does with Aslan, or God) Pullman enriches love with meaning, giving it a greater purpose and presence in his work. He seemingly intends to make his own work one which is more virtuous than Narnia.

\footnotetext{
${ }^{297}$ Spyglass, 419.

298 Spyglass, 426-427.

2991 Thessalonians 5.2 (NRSV)

${ }^{300}$ Matthew 17.20 (NRSV)
} 
Pullman's passionate objection to Narnia prevents him from responding to it objectively, and he frequently responds to his misconceptions about Lewis's series. In his response to Narnia Pullman misreads the earlier series, swerving from the meaning of the original text and bringing it to different conclusions so that his series presents a different ideology and meaning to Lewis's series.

His Dark Materials is an ambitious work, vying with prestigious texts. In his acknowledgment of influences, and the unavoidable connection with Narnia, Pullman places himself alongside Blake, Milton, and Lewis. His comments indicate that he does not expect to surpass Blake and Milton in terms of greatness, referring to them as "better writers" in his acknowledgements in The Amber Spyglass. Kleist's essay is a less easily recognised source, and though Pullman includes him in the group of "better writers" His Dark Materials has certainly become more widely read and better known than the Kleist essay. The influence is mutually beneficial, as Pullman took a theme from Kleist's work while his trilogy directs readers who would otherwise be unaware of it towards "On the Marionette Theatre".

Though Pullman graciously acknowledges these works there can be no doubt that he wishes (and believes himself) to surpass Lewis's series. Pullman objects to Lewis's (admittedly forceful) presentation of Christianity, but is equally forceful in his presentation of atheism. His technique is equal to Lewis's, as each author's ideologies occasionally dominate the fantasy stories they tell. It remains to be seen whether His Dark Materials will find a place alongside Narnia in the realm of classic Children's Literature. 


\section{Chapter Three}

\section{Pullmanian Ideas in Westerfeld's Extras: An Exercise in Hermeneutics}

In October 2007 Westerfeld published Extras, a companion novel to the Uglies series. There are similarities between this novel and Pullman's His Dark Materials, which is intriguing as the similarities are not present in the earlier Uglies texts. The following month Westerfeld wrote on his internet blog that The World of the Golden Compass: The Otherworldly Ride Continues (an anthology of essays about His Dark Materials which he had spent "most of this summer" editing) was available at Borders bookstores. ${ }^{301}$ Interestingly, the influence Pullman appears to have had on Extras comes via the mediation of critics - the links between Extras and two essays in the anthology leave a clearer trail than the links between Extras and His Dark Materials itself. Unlike the other influences discussed in this thesis Westerfeld neither acknowledges nor attempts to conceal Pullman's influence on his work - he may not have even been aware of the influence as he was writing Extras, and it may be a by-product of Westerfeld's simultaneous immersion in Pullman's series as he compiled and edited The World of the Golden Compass.

Engaging with hermeneutics is helpful in illustrating this influence in what can only be a speculative exercise. Though Pullman's influence on Westerfeld does not perfectly fit a hermeneutical model, hermeneutical terms help to explain Westerfeld's interpretation of Pullman's trilogy.

\footnotetext{
${ }^{301}$ Scott Westerfeld, "Inside the Golden Compass", 23 November 2007, http://scottwesterfeld.co $\mathrm{m} / \mathrm{blog} / 2007 / 11 /$ inside-the-golden-compass/. (accessed 13 March 2010).
} 
Friedrich Schleiermacher is one of the founding figures in the study of hermeneutics. He has left a famous legacy, as his universal theory of hermeneutics applied interpretation theory to all modes of communication instead of exclusively to sacred texts. Part of his theory proposes that misreading a text is natural, a consequence of the reader's hastiness and prejudice, ${ }^{302}$ and both of these factors have a role in Westerfeld's use of His Dark Materials. He almost certainly would have read His Dark Materials prior to editing The World of the Golden Compass, but he would have had little time between reading the anthology's essays and writing Extras, so hastiness may have contributed to his misreading of Pullman's series. Prejudice is a more significant factor in Westerfeld's misreading, and will be explored in this chapter. It is defined by Schleiermacher as "the one-sided preference for what is close to the individual's circle of ideas and the rejection of what lies outside it." ${ }^{303}$ In his reading of Pullman's series, Westerfeld shows a preference for the Science Fiction genre and the ideas expressed by essayists in The World of the Golden Compass.

Schleiermacher distinguishes between "psychological" and "grammatical" interpretation, though he argues that both are necessary for a cohesive interpretation of a text. The objective of psychological interpretation is to identify the author's way of thinking. The interpreter attempts to discover "the principle which moves the writer", ${ }^{304}$ which is Westerfeld's objective in his introduction to The World of the Golden Compass. In it he speculates about the origins of Pullman's ideas and comes to a conclusion which is remarkably similar to his explanation of the origins of his own ideas.

\footnotetext{
${ }^{302}$ Friedrich Schleiermacher, Hermeneutics and Criticism and Other Writings, trans. Andrew Bowie (Cambridge: Cambridge University Press, 1998), 23. (Hereafter referred to as Hermeneutics.)

${ }^{303}$ Hermeneutics, 23.

${ }^{304}$ Hermeneutics, 90.
} 
Grammatical interpretation is concerned with the linguistic features of a text, and Schleiermacher's first canon of grammatical explication is applicable to the relationship between the Uglies series and His Dark Materials. It states "Everything in a given utterance which requires a more precise determination may only be determined from the language area which is common to its author and his original audience." ${ }^{305}$ An author and their audience must share the same language if the text is to be correctly understood. Lawrence Schmidt observes that "To interpret a statement from the contemporary understanding of language, when that statement comes from a previous use of language, leads to misunderstandings". ${ }^{306}$ Westerfeld and Pullman use different languages in their series. They are not literally different languages, of course - each writes in English - but they could be considered different dialects. Westerfeld writes in a language that is partly derived from Science Fiction and partly of his own invention as he creates and uses his own slang without explaining the meaning of the words. ${ }^{307}$ Pullman is influenced by fantasy and history, his writing evocative of his background as a teacher and experience in the Church of England. Schleiermacher asserts that a reader's misunderstanding "is often the fault of attributing a particular meaning to already existing expressions." "308 This is what Westerfeld does with the terms "daemon" and "story", as his interpretation of them has a technological bent which is absent in Pullman.

Westerfeld performs both an exegesis and eisegesis in his reading of His Dark Materials. Exegesis is defined as the objective interpretation of a text and is made by deriving meaning from the text itself, while eisegesis is a subjective interpretation in which the interpreter reads their own ideas onto a text. Westerfeld's

\footnotetext{
${ }^{305}$ Hermeneutics, 30.

${ }^{306}$ Lawrence K. Schmidt, Understanding Hermeneutics, (Stocksfield: Acumen, 2006), 16.

${ }^{307}$ In a similar, but much less extreme, way to that of Anthony Burgess in Clockwork Orange (1962).

${ }^{308}$ Hermeneutics, 33.
} 
overall reading of His Dark Materials, as it can be seen in The World of the Golden Compass and Extras, is a combination of exegesis and eisegesis. His account of Pullman's ideas is an eisegesis, suspiciously similar to his account of his own ideas. He draws Pullman-like conclusions regarding truth and lies, making an exegesis of His Dark Materials. His interpretations of "daemons" and "stories", when looked at from a grammatical interpreter's point of view, are instances of eisegesis. However, their functions in Westerfeld's work are similar to their functions in Pullman's, suggesting that this is a deliberate eisegesis or misreading, and that Westerfeld has also made an exegesis of the text - he has understood the meaning of the text in order to deliberately misread it.

In his attempt to identify the origins of Pullman's ideas Westerfeld mistakenly supposes Pullman to think in the same way he does. Westerfeld describes the origins of gadgets and objects which populate his own series in Bogus to Bubbly:

I get asked a lot where the futuristic inventions in Uglies come from. How did I get all these crazy ideas? Well, I mostly didn't. Only a few of Tally's gadgets are original to me. Most have a long history in science fiction, and a couple already exist in the here and now. ${ }^{309}$

Turning to specific inventions he identifies their origins in the Science Fiction genre, research laboratories, and modern technology. The aspects of Tally's world exist in an imagined future which may become a reality through scientific developments. Westerfeld's speculation on the source of Pullman's ideas follows a similar pattern. Beginning the introduction of The World of the Golden Compass Westerfeld identifies aspects of arctic exploration in the 1800s which appear in His Dark Materials and concludes:

${ }^{309}$ Bogus, 99. 
So let's review: cosmic dust, meteoric iron, needles swinging lazily on compasses, and floating cities that augur hidden worlds. Does any of this sound familiar? ${ }^{310}$

Pullman, he suggests, "makes his fictional world from out-of-date pieces of the real one." ${ }^{311}$ Westerfeld's world is constructed from futuristic inventions, and he suggests that Pullman's is made of things which were once considered real, and magical, before science provided mundane explanations for them. He has imported his own concerns into his interpretation of Pullman and made an eisegetic reading. Pullman, who reads like a butterfly and writes like a bee, would not be concerned about the compatibility of aspects of his world outside the context of the story. Instead, he appropriates aspects from a variety of sources and combines them to create the world of His Dark Materials.

A Young Adult text which did not engage with the theme of truth and lies would be unusual, and this theme is a prominent one in His Dark Materials. It also has a significant presence in Extras. Pullman's influence on Westerfeld is evident, as this theme only lurks in the background of the three books written prior to Westerfeld editing The World of the Golden Compass. The theme is treated similarly in each author's work, evident in the depictions of society. The "God" who rules the world of His Dark Materials is a liar, and his lies are perpetuated by a powerful church which actively suppresses truth, through inquisition, exorcism, torture, and execution. John Parry remarks that "We've had nothing but lies and propaganda and cruelty and deceit for all the thousands of years of human history. It's time we

\footnotetext{
${ }^{310}$ World, 3.

${ }^{311}$ World, 4.
} 
started again". ${ }^{312}$ Lyra and Will intend to "start again" at the series' conclusion as they resolve to build the Republic of Heaven. The society in Extras has "started again", having realised that they had been brainwashed and controlled by the authorities. Aya echoes John Parry's comment when she thinks that "It was so easy to believe in conspiracies, after the government had made everyone brain-missing for

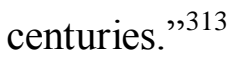

A more significant characteristic of this influence is that it is mediated through Carole Wilkinson's essay “Pants on Fire”. Westerfeld obviously admires the content and ideas of the essay, as he selected it to be the first essay in The World of the Golden Compass and admits that when he took part in a roundtable discussion of His Dark Materials at Boston University he "stole some good lines from Carol [sic] Wilkinson's essay in the HDM anthology [he] edited to talk about the importance of truth and lies in the trilogy." ${ }^{114}$ Wilkinson's analysis of Pullman's series, and the conclusions she makes about truth and lies in the trilogy, are noticeably present in Extras. Wilkinson asserts that "Often in works of fiction, it's easy to tell the goodies from the baddies, because the goodies tell the truth, whereas the baddies lie through their teeth", ${ }^{315}$ and then explains why this is not the case in His Dark Materials. Bears are the only characters in the trilogy who cannot lie, the other characters lie with ease. Characters tell well-intentioned lies (the Master of Jordan telling Lyra she is an orphan, believing it to be in her best interests) and self-serving lies (Mrs Coulter lies for her own benefit). Even Lyra, Pullman's heroine, lies. An

\footnotetext{
${ }^{312}$ Knife, 334.

${ }^{313}$ Extras, 37.

${ }^{314}$ Scott Westerfeld, "Not Banned in Boston”, 8 December 2007, http://www.scottwesterfeld.com /blog/?p=348. (accessed 17 February 2010).

315 Carole Wilkinson, "Pants on Fire: Truth, Lies, and Deception in The Golden Compass". In The World of the Golden Compass: The Otherworldy Ride Continues, edited by Scott Westerfeld, 5-14, (USA: BenBella Books, 2007), 5. (Hereafter referred to as "Pants".)
} 
accomplished storyteller, she boasts "I'm the best liar there ever was". ${ }^{316}$ Her name evokes both "liar" and "lyre", implying that there is a fine line between outright lies and stories intended to entertain as a lyre player would. Interestingly, it is Lyra the liar who is given the alethiometer. Wilkinson notes that though she possesses the truth-measure "lying is still an integral part of Lyra's strategy." alethiometer, Lyra possesses a control of truth in addition to her mastery of the skill of lying. Both are weapons at her disposal, and she chooses to use both for honest purposes. The lies she tells to Iofur Raknison enable Iorek to claim the throne which is rightfully his. The truths she tells Mary Malone about Dust convince Mary to show Lyra her own experiments with Dust and to help her and Will throughout the remainder of the series. Pullman uses Lyra's experiences to suggest that a lie can be good or bad, but a person has the potential to be either.

Westerfeld makes the same point in his series but uses more characters to do so, and does so less subtly. His protagonist Aya lies like Lyra, and her name also sounds similar to "liar". ${ }^{318}$ Aya lies and "truth-slants" for her own advantage, but her lies - while they may initially benefit her - always generate a negative consequence. She tells the Sly Girls that she is no longer a "kicker" and will not bring Moggle (her hovercam) with her if they allow her to join their surfing expedition. They believe her, and she takes Moggle to go surfing. $\mathrm{Ai}^{319}$ and Eden both become suspicious of her when she lies again, telling them that she has heard a train coming (rather, she had seen it on a picture Moggle had taken). Ai "narrowed her eyes [and asked]

\footnotetext{
${ }^{316}$ Knife, 107.

317 "Pants", 9.

${ }^{318}$ Westerfeld's explanation that he wanted the character's name to sound like "eye" notwithstanding. (Bogus, 134.)

${ }^{319}$ Westerfeld explains that $\mathrm{Ai}$ is the real name of the character who successively calls herself Jai, Kai, and Lai: "Ai is the secret real first name of Jai/Kai/Lai, the name-shifting leader of the Sly Girls. Every time she gets too famous, she just sticks another consonant in front." (Bogus, 136.)
} 
'What makes you think that?",320 and Eden does not believe Aya heard the train from such a distance: “When I first got here, I couldn't feel anything. Not till the train was much closer. But you noticed if from way back inside the mountain." ${ }^{321} \mathrm{Ai}$ and Eden's suspicion of Aya continues, and they ultimately shoot her out of a "mass driver" on a sled because they know she has lied to them. Ai asks Aya incredulously whether she thought they "really believed you heard that train when it was fifty kilometers away?"322 Though Aya does not initially face any retribution for her lie, she cannot escape its punishment. This illustrates part of Pullman's statement about truth and lies - some lies are harmful.

Aya, although she lies herself, is shocked when she is lied to. In school she had been taught that Tally was a great hero, and is stunned to realise after an encounter with her that "Tally Youngblood - architect of the mind-rain, the most famous person in the world - was nothing but a truth-slanting Slime Queen. ${ }^{, 323}$ She confronts Tally and, continuing to show astonishment that Tally would lie, repeats: “you lied to us!",324 In a sharp contrast, the characters in His Dark Materials expect to be lied to. Will, realising that Mrs Coulter has lied to him about Lyra, calmly remarks to Iorek that "She's lying ... Of course she's lying. She'd lie even if it made things worse for herself, because she just loves lying too much to stop." ${ }^{325}$ Initially, Westerfeld forcefully and obviously makes the assessment that lying is intolerable, while Pullman never makes such an explicit statement.

\footnotetext{
${ }^{320}$ Extras, 137.

${ }^{321}$ Extras, 142.

${ }^{322}$ Extras, 177-178.

323 Extras, 276.

${ }^{324}$ Extras, 280-281.

325 Spyglass, 150.
} 
Frizz's engagement with "Radical Honesty", a group of people who undergo a surgery leaving them unable to lie or deceive people, brings the novel to a more Pullmanian conclusion. He explains why he started this clique:

"I used to lie ... constantly ... Sometimes for a reason, but mostly just for fun. I was always pretending, making up a new Frizz for everyone I met - especially, you know, girls ... But I started to forget who I really was ... I wanted to see what it was like without lies.”326

Frizz discovers the world is no better without lies. Ren observes that "if you never lie, there's always someone mad at you", ${ }^{327}$ and Frizz eventually concedes that "sometimes you have to lie to find the truth", ${ }^{328}$ a sentiment which could have come directly out of His Dark Materials. He abandons Radical Honesty, reopening himself to the possibility of telling lies. Frizz shows - as Pullman does - that lies have a place.

Wilkinson surmises that in His Dark Materials "ultimately, it's truth that's important", 329 and Westerfeld comes to the same conclusion. Aya says at the close of Extras that she wants Frizz to keep her honest, ${ }^{330}$ and Frizz (though he has abandoned Radical Honesty) wants to tell the truth on his own accord.

Westerfeld makes the same statement about truth and lies that Pullman does, but does so a lot less subtly. Through two characters he presents two (extreme) opposing views and affirms each. Pullman uses one character to illustrate the point that truth and lies can be equally valid depending on their circumstance.

Westerfeld's reading of His Dark Materials, defined in the way each author treats the theme of truth and lies, is an exegesis. Extras eventually agrees about the importance of truthfulness and the validity of lying. It is highly probable that

\footnotetext{
${ }^{326}$ Extras, 238.

${ }^{327}$ Extras, 43

${ }^{328}$ Extras, 204

329 "Pants", 13

${ }^{330}$ Extras, 415.
} 
Westerfeld's reading was influenced by Wilkinson's essay. She makes several succinct points about Pullman's series. Pullman subtly illustrates his argument that truth and lies can be used for different purposes (with varying degrees of intention), which Wilkinson surmises in statements such as "Lies can be bad, but used against evil they're okay". ${ }^{331}$ Westerfeld is equally blunt in assessment his characters make although he makes the same point as Pullman, he makes it in the same manner as Wilkinson.

Wilkinson's essay would have directed Westerfeld towards the importance of stories in His Dark Materials as she spends a paragraph discussing Lyra's encounter with the harpies. Stories are similarly important in Extras, although Westerfeld's interpretation of "story" is different to Pullman's. Wilkinson remarks that the story Lyra tells No-Name is "a complete fabrication, the sort of story she would make up to amuse the kids in Oxford." 332 This story, and the story she later tells in the cold and dark land of the dead, recall a storytelling in a medieval mead hall in a cold and dark English winter. Lyra obviously intends to entertain her audience, as she plans her story "shaping and cutting and improving and adding: parents dead; family treasure; shipwreck; escape ..."333 Her audience listens "solemn and spellbound" 334 and it is a "storytelling" in the traditional sense of the word. But Westerfeld uses "story" in a more modern sense. The stories people post on their "feeds" are akin to news stories on television or the internet, incorporating images, video, and sound. The different "languages" Westerfeld and Pullman use in interpreting the term

\footnotetext{
331 "Pants", 9.

332 "Pants", 12.

333 Spyglass, 307.

334 Spyglass, 331.
} 
"story" mean that Westerfeld makes an eisegesic reading of His Dark Materials. This misreading is deliberate, as similarities between each text's treatment of stories shows that he has understood their significance in Pullman's trilogy.

Stories, in His Dark Materials, help people to progress. The story Mary Malone tells Will and Lyra encourages them to fall in love, and they then make the transition from childhood into adulthood. Without a story to tell, ghosts would be stuck forever in the unnatural land of the dead. Salmakia has instructed the harpies:

"Your task will be to guide the ghosts from the landing-place by the lake all the way through the land of the dead to the new opening out into the world. In exchange, they will tell you their stories as a fair and just payment for this guidance."335

The dead desire to leave the land of the dead through this "new opening" and be absorbed into the living world, and they need to tell a story to do so.

In Extras people publish stories on their feeds to build their fame and reputation. The "reputation economy" in Aya's city uses fame in the place of money. Somebody who is famous can use more of the city's resources than someone who is not. People who become famous because of the stories they "kick" are similar to those in the world outside of fiction who receive promotions and pay rises and advance on a career path.

Lyra and Aya both learn (via a harsh lesson) that stories must be true. They each initially tell untrue stories, though they do not consider them untruthful. Lyra tells No-Name a story which, while it is a piece of fiction, contains elements of truth. She adds to and alters it to make it more interesting, which enrages the harpy. NoName flies at Lyra, screaming "Liar!", and tears out a clump of her hair, leaving Lyra sobbing in shock. ${ }^{336}$ Aya "truth-slants", altering some of the shots in a story she

\footnotetext{
335 Spyglass, 334.

336 Spyglass, 308.
} 
"kicks". Though she is not lying she has told an untrue story. Hiro explains, "when you pick and choose facts to make your story, you always wind up truth-slanting. That's why good kickers put everything up."337 Glumly, Aya realises that people doubt her story and believe she is deliberately hiding something, and knows that if her story is proven wrong people will "gleefully jump on [her]"338 - as No-Name jumped on Lyra. Aya's story does not have negative repercussions solely for her - it causes Tally to wrongfully attack the Extras, creating a great deal of destruction.

Having told untrue stories, both girls then tell a true story. Lyra tells the ghosts and harpies about her life and they all listen, enraptured. Perplexed, she asks the harpies why they did not attack her. No-Name replies:

"Because it was nourishing. Because it was feeding us. Because we couldn't help it. Because it was true. Because we had no idea that there was anything but wickedness. Because it brought us news of the world and the sun and the wind and the rain. Because it was true.”339 Aya edits her story so that it contains all the facts, which helps the Extras to get recruits for the civilisation they are establishing in orbit. ${ }^{340}$ In each text a true story causes positive consequences while telling a false story creates trouble.

Westerfeld's interpretation of "story" is different to Pullman's. This has been a deliberate choice on Westerfeld's part because stories in each text function similarly, showing that he has understood the original meaning.

Extras begins in a similar way to Pullman's series. Northern Lights opens with the sentence "Lyra and her daemon moved through the darkening Hall, taking

${ }^{337}$ Extras, 234.

${ }^{338}$ Extras, 334.

${ }^{339}$ Spyglass, 332-333.

${ }^{340}$ Extras, 412. 
care to keep to one side, out of sight of the kitchen." ${ }^{341}$ Pan is then revealed to be in the shape of a moth, and acts as a lookout for Lyra as he flies into the Retiring Room to check that there is no one there. This is obliquely paralleled in Extras, which begins:

"Moggle," Aya whispered. "You awake?"

Something moved in the darkness. A pile of dorm uniforms rustled, as if a small animal stirred underneath. Then a shape slipped from among the folds of spider silk and cotton. $^{342}$

Moggle is introduced in conjunction with Aya, as Pan is with Lyra. The likening of Moggle to a "small animal" recalls Pan in his initial form of a moth, or in one of his other forms - an ermine, a mouse, or a bird. Moggle's animal nature is further stressed when Aya is seen "stroking its sprayed-black plastic shell"343 in an apparent effort to comfort it. Like Pan, Moggle acts as a lookout when it checks if there is a way for Aya, Ren, Hiro, and Frizz to escape the storm drains. ${ }^{344}$ As each series advances, Moggle and Pan endure a watery abandonment. Pan is left on the shore as Lyra is ferried across to the land of the dead, an act which drives Lyra to tears. Aya chooses to have Moggle dropped into a lake so that she can go surfing with the Sly Girls, and her eyes "stung with hidden tears" 345 as it splashed into the water.

These parallels between His Dark Materials and Extras show that links can be drawn between Moggle and daemons, but there are even stronger links between Moggle and Diana Peterfreund's essay "Ghost in the Machine", in which she proposes that a laptop can be considered a daemon. Peterfreund claims that a laptop fulfils many of a daemon's roles - something she realised after her laptop died,

\footnotetext{
${ }^{341}$ Lights, 3.

${ }^{342}$ Extras, 3.

343 Extras, 125.

${ }^{344}$ Extras, 241.

${ }^{345}$ Extras, 29.
} 
leaving her feeling "severed" from a part of herself. ${ }^{346}$ Moggle is a hovercam, and like Peterfreund's laptop - is primarily a machine. Peterfreund found three significant similarities between her laptop and daemons, which also apply to Moggle: each shares experiences with its human, reflects their personality, and provides them with companionship. As he does with "story", Westerfeld - writing in a different "language" - interprets "daemon" differently to Pullman. His reading is a deliberate eisegesis, as Moggle and daemons function similarly.

Daemons share experiences with their humans. Peterfreund likens Pan's changing forms as he journeys with Lyra (he is a dolphin when she is on a gyptian boat, and a mountain goat when she climbs mountains) to a laptop storing holiday experiences in the form of photographs. ${ }^{347}$ Moggle, too, shares experiences with Aya, but in a way that is more akin to the laptop than to Pan. It records and stores images of her adventures, which gives Aya a sense of authenticity. She wants everything she does to be recorded, and is scolded by Tally: "Don't worry, Aya-la ... You'll still be real, even with no hovercam watching." ${ }^{348}$ This sentiment has some similarity with His Dark Materials, as someone without a daemon is soulless and unreal - but is more strongly connected to Peterfreund's description of her laptop as "the bearer of memory in the form of more than a thousand photos of my journeys abroad". 349

A daemon is a reflection of a human's personality: Pan shares and exhibits the same emotions as Lyra. Peterfreund describes how a laptop can reflect its owner's personality, referring specifically to people creating avatars for online role-

\footnotetext{
${ }^{346}$ Diana Peterfreund, "Ghost in the Machine". In The World of the Golden Compass: The Otherworldy Ride Continues, edited by Scott Westerfeld, 93-102, (USA: BenBella Books, 2007), 95. (Hereafter referred to as "Ghost".)

347 "Ghost", 95.

348 Extras, 324.

349 "Ghost”, 94.
} 
playing games such as World of Warcraft and Second Life. ${ }^{350}$ This draws attention to a significant difference between laptops and daemons. Humans, in His Dark Materials, cannot create their own daemons - "much to the dismay of Iofur Raknison”. ${ }^{351}$ An avatar - while it can possess the same physical and personality traits of its creator - is ultimately a personal construct, created by someone to appear and function in a way they desire. Aya's use of Moggle is more akin to someone's use of an avatar than to a daemon. She uses it to put stories and pictures on her feed, and she is selective about what these are and how these are edited. This is a clear indication that Peterfreund's essay about daemons had a stronger influence on Westerfeld than His Dark Materials itself.

Peterfreund attests: "When I was with my laptop, I was never subject to that most desolate of Pullmanian horrors: being alone." ${ }^{352}$ Without her laptop, she lost access to her emails, blogs, and internet communities, as well as the social interaction they enabled. Characters in His Dark Materials are never alone when they are with their daemons, but those who are separated lose a part of themselves and become zombie-like: "A human being with no daemon was like someone without a face, or with their ribs laid open and their heart torn out; something unnatural and uncanny that belonged to the world of night-ghasts, not the waking world of sense." ${ }^{353}$ Without Moggle, Aya feels similarly "cut off from the world, unreal." ${ }^{354}$ Comparing the loss of Moggle to "looking down on a sunny day to find her shadow gone", ${ }^{355}$ Aya implies that Moggle is a part of her, in the same way daemons are a part of their human.

\footnotetext{
350 “Ghost”, 98.

351 "Ghost", 99.

352 "Ghost", 96.

${ }^{353}$ Lights, 215.

${ }^{354}$ Extras, 52.

${ }^{355}$ Extras, 18.
} 
Westerfeld, in Bogus to Bubbly, indicates that his primary reason for creating Moggle was to provide a companion for Aya:

Here's why I created Moggle, Aya's hovercam: Aya spends a lot of time on her own, a scenario that tends to bog down a story ... So I decided that a sidekick would help Aya's solo scenes. Even though Moggle doesn't say anything, the hovercam gives Aya someone to talk to and worry about. ${ }^{356}$

Clearly, Westerfeld sees Moggle as a character and not merely as a machine. Aya talking to and worrying about Moggle is reminiscent of Lyra doing the same with Pan. In the pairing of Lyra and Pan, the daemon also experiences feelings. He is described as "bitter and cold and frightened" ${ }^{357}$ when Lyra leaves him behind to go to the land of the dead. Westerfeld's statement in Bogus to Bubbly implies that the relationship between Aya and Moggle is one-sided, but Moggle's treatment in Extras contradicts this. Moggle is frequently described as if it has feelings, though it (as a machine) obviously does not. After it has been thrown in the water Aya apologies to Moggle, as if she needs to make amends and repair their relationship. She later informs Tally that "Moggle doesn't like being left alone." 358 This is an odd statement to make if Moggle is merely a machine, but not if Moggle is meant as Aya's "daemon".

Moggle is clearly intended as a companion for Aya, and is similar to a daemon - and even more similar to Peterfreund's description of her laptop as a daemon. Westerfeld has been influenced by Peterfreund's essay in his reading of His Dark Materials and interpretation of "daemon". As with his reading of "story", he is aware that his depiction of a "daemon" is different to Pullman's. Though Moggle is a machine and Pan is a sentient being they function similarly in their texts,

\footnotetext{
${ }^{356}$ Bogus, 108.

357 Spyglass, 298.

358 Extras, 265.
} 
showing that Westerfeld has understood the original, Pullmanian meaning of "daemon".

Extras is notably different to the three Uglies books which preceded it. It has a new setting, is filled with new characters and gadgets, and engages with new themes. It displays a Pullmanian influence which is mediated through critics who wrote essays for The World of the Golden Compass. The thematic treatment of truth, lies, and stories in Extras displays Westerfeld's understanding of both His Dark Materials and Wilkinson's reading of it. There are similarities between Moggle and Pullman's depiction of daemons, and clearer similarities between Moggle and Peterfreund's account of how her laptop fulfils the role of a daemon. In his appropriation of these aspects Westerfeld has made an exegesis and deliberate eisegesis of Pullman's text, though his theory of the origins of Pullman's ideas - so similar to his account of the origins of his own ideas - is an accidental misreading.

Unlike the other influences discussed in this thesis, Pullman's influence on Westerfeld is neither one he acknowledges nor attempts to hide. As he was writing Extras and editing The World of the Golden Compass simultaneously, Pullmanian ideas may have unwittingly entered his own work. Moggle being treated as if it is sentient, despite Westerfeld's description of Moggle as a simple machine that "doesn't say anything", ${ }^{359}$ is a clear illustration of this. Intentional or not, Extras has some uncanny similarities to His Dark Materials.

${ }^{359}$ Bogus, 108. 


\section{Conclusion}

The aim of this thesis was to examine the literary influences present in Uglies and His Dark Materials and to see whether these two similar series - trilogies, for Young Adult audiences, with female teenage protagonists who discover that their world is not what they thought it was - were similar in their use of influences. The thesis was also intended as a close reading of the two authors' works, to further the field of criticism about Philip Pullman's His Dark Materials, which is substantial but not crowded, and to help to establish the currently scarce field of criticism about Scott Westerfeld's Uglies series. While there has been little critical writing regarding Westerfeld, this thesis has highlighted the merits of such an endeavour, as Uglies draws on and implicitly critiques well known works which are themselves subject to critical attention. A summary of the main findings follows.

Westerfeld and Pullman each acknowledge a core group of texts as influences. Pullman names three works as "debts that need acknowledgement above all the rest $" 360$ in The Amber Spyglass. Westerfeld openly acknowledges two texts as influences on his Amazon profile page and a further two in his introduction to MindRain. There is no difference in the degree of acknowledgement Westerfeld and Pullman give to their influences, but there is a difference in the way they use these texts in their own work.

Pullman's use of Kleist's essay "On the Marionette Theatre" is the most direct borrowing of the seven texts surveyed. Essentially, His Dark Materials is the same story that Kleist tells. Pullman borrows both a fighting bear and the theme of conscious and unconscious grace from Kleist and uses them in his own story. By

${ }^{360}$ Spyglass, 549-550. 
applying the worldview of Kleist's essay to His Dark Materials Pullman tests it and finds it to be transportable to his own text, fitting his characters and story as well as it fits Kleist's.

Westerfeld adopts the setting of "The Beautiful People". His story is remarkably similar to Beaumont's but continues after Beaumont has finished. Though "The Beautiful People" ends with Mary about to undergo the Transformation, Westerfeld continues for two books after Tally becomes pretty. Westerfeld brings Beaumont's story to completion.

Though the series' plots are different, Westerfeld adopts and adapts Caps from Christopher's Tripods series. Capping and the Operation are similar in their procedure and function, thematically linked as both are a means of social control. Uglies retains the theme of the Tripods series, though the series tells a different story.

Pullman borrows aspects of Blake's poetry, and alludes to it throughout his own series. Much of what is borrowed is not adapted - if an aspect of Blake's work is not compatible with His Dark Materials Pullman ignores it. His Dark Materials affirms Pullman's "selective credo" which he acknowledges as being derived from Blake's work.

Uglies is a reversal of many aspects of Chiang's "Liking What You See". Westerfeld begins by reversing the effects of the operation in Chiang's text so that the Operation in his own is different. Despite the many points of difference between the texts they share the same theme. Westerfeld's work, however, focuses primarily on Tally as a character, while Chiang's work focuses on the issue of a voluntary operation, and of the two texts Uglies is therefore more suited to a Young Adult audience. 
Pullman, in Bloom's sense, deliberately misreads Paradise Lost. He retains the skeletal structure of Milton's epic but rewrites it so that the meaning is changed in His Dark Materials. That elements of Milton are present in Pullman indicates a level of copying, that the elements are transformed shows that it is not a straight borrowing, and the result is that His Dark Materials presents a different worldview to Paradise Lost.

The influence of Bradbury's Fahrenheit 451 on Uglies is the least obvious of the seven acknowledged influences investigated. The links between the works are largely thematic, having to do with social control, and the two authors' treatments of these themes vary. Westerfeld connects the works by asserting that book-burning and the Operation are similar, a connection that might not otherwise be obvious.

Westerfeld and Pullman use these influences similarly - they are equally acknowledged and involve a degree of copying or borrowing. The ways in which they treat their concealed influences, however, are different. Westerfeld never acknowledges Brave New World as an influence on Uglies, despite others making the connection. Seemingly he does not want to call attention to the influence for fear of his own work appearing a weak imitation of Huxley’s. Pullman is famously vocal in his distaste for Lewis's The Chronicles of Narnia. Though he remains coy when asked about the apparent influence this series has had on his own work, he has allowed for the possibility that Lewis's work is a precursor to his own. Uglies and His Dark Materials each show two degrees of influence. The first, straight borrowing, is present in both series. Westerfeld's reservation is similar to Huxley's Reservation, and his character Andrew Simpson Smith is analogous to Huxley's character John Savage. Pullman's work shows a straight borrowing from Lewis in its use of a wardrobe and the journeys characters make between worlds. For Westerfeld, 
the second degree of influence is refunctioning. He appropriates other aspects of Huxley's text but refunctions them so that the story becomes relevant to a Young Adult audience. Aspects which are in the background in Huxley's work are brought to the foreground in Westerfeld's, and vice versa. The overarching meaning of the text remains the same, but the emphasis changes. Westerfeld, in appropriating Brave New World, adopts its viewpoint but not its priorities. The same cannot be said for Pullman and Narnia. Having initially borrowed from Lewis, the second degree of influence in His Dark Materials is the way in which it swerves from the earlier series in a corrective manner. The influence of Narnia is evident through its absence and replacement. The lack of a spiritual Heaven in the later series, for instance, shows a deliberate choice on Pullman's part not to include this prominent aspect of The Last Battle. Pullman clearly disagrees with the worldview presented in Narnia and offers his own opposing view in His Dark Materials.

The third chapter of this thesis further complicated the matter of influence. It illustrated the subjectivity present in one's reading of a text and how, if the reader is also a writer, this prejudice can appear in their own work. Westerfeld's reading of Pullman is subject to his own ideas, and the influence His Dark Materials had on Extras was strongly mediated through two critical essays on Pullman's series.

Many means of appropriating an earlier text lie within Uglies and His Dark Materials, such as straight borrowing, allusion, misreading, correcting, and refunctioning. If Pullman and Westerfeld are representative, a writer may have multiple attitudes to their literary influences. Westerfeld happily acknowledges four precursor texts, but his silence on a fifth is seemingly due to an anxiety that he has not surpassed, improved, or significantly changed Huxley's work. Pullman happily acknowledges three literary influences, but may be embarrassed by the similarities 
between his work and Lewis's - he would not want people to think that his work owes any debt to this precursor whom he has such distaste for - or worse, think that his work presents a similar viewpoint. Literary influence, and relationships between precursor and latecomer texts, are by no means straightforward. An examination of either of these texts shows that one author, in one text, can both happily reveal their influences and attempt to conceal them. 


\section{Bibliography}

Bandy, Melanie. Mind Forg'd Manacles: Evil in the Poetry of Blake and Shelley. Alabama: University of Alabama Press, 1981.

Beaumont, Charles. 1952. "The Beautiful People." In Mind-Rain, edited by Scott Westerfeld, 133-154. Dallas: BenBella Books, 2009.

Behrendt, Stephen C. The Moment of Explosion: Blake and the Illustration of Milton. Lincoln: University of Nebraska Press, 1983.

Blake, William. 1810. “A Vision of the Last Judgement.” In The Complete Poetry and Prose of William Blake, edited by David V. Erdman, 554-566. New York: Anchor Books, 1982.

---. Blake: The Complete Poems. $3^{\text {rd }}$ Ed. Edited by W. H. Stevenson. London: Pearson Longman, 2007.

---. 23 October 1804. "Letter to William Haley," In The Letters of William Blake, edited by Frederick Tathum and Archibald George Blomefield Russell, 168-172. New York: C. Scribner's Sons, 1906. http://www.archive.org/strea $\mathrm{m} /$ letterswilliamb00tathgoog. (accessed 13 February 2010).

---. Milton. Edited by Kay Parkhurst Easson and Roger R. Easson. Colorado: Shambhala, 1978.

---. Songs of Innocence and of Experience. Edited by Robert N. Essick. San Marino, California: Huntington Library and Art Gallery, 2008.

Bloom, Harold. A Map of Misreading. New York: Oxford University Press, 1975.

---. The Anxiety of Influence: A Theory of Poetry. $2^{\text {nd }}$ Ed. New York: Oxford University Press, 1997.

Bradbury, Ray. 1953. Fahrenheit 451. Reprint, London: Corgi Books, 1967.

Burgess, Anthony. 1962. A Clockwork Orange. Reprint, New York: Norton, 1988.

Chiang, Ted. 2002. "Liking What You See: A Documentary." In Mind-Rain, edited by Scott Westerfeld, 155-196. Dallas: BenBella Books, 2009.

Christopher, John. 1967. The City of Gold and Lead. Reprint, New York: Aladdin Paperbacks, 1988.

---. 1967. The White Mountains. Reprint, Middlesex: Kestrel Books, 1984. 
---. 1968. The Pool of Fire. Reprint, Middlesex: Kestrel Books, 1984.

Clark, Tristan. "The Christian, the Atheist, and the Critics: An Analysis of Philip Pullman's His Dark Materials in Relation to C. S. Lewis's Narnia." Honours research essay, Victoria University of Wellington, 2007.

Conolly, Tristanne J. William Blake and the Body. New York: Palgrave Macmillan, 2002.

Cowart, David. Literary Symbiosis: the Reconfigured Text in Twentieth-Century Writing. Athens, Ga: University of Georgia Press, 1993.

Craig, Amanda. "The Future Imperfect." Times Online 11 November 2006. http://entertainment.timesonline.co.uk/tol/arts_and_entertainment/books/chil dren/article1087081.ece. (accessed 23 November 2009).

Crasnow, Ellman. "Hermeneutics." In The Routledge Dictionary of Literary Terms, edited by Peter Childs and Roger Fowler, 103-105. London: Routledge, 2006.

Doskow, Minna. William Blake's Jerusalem: Structure and Meaning in Poetry and Picture. London and Toronto: Associated University Press, 1982.

Eagleton, Terry. "Refunctioning." In The Routledge Dictionary of Literary Terms, edited by Peter Childs and Roger Fowler, 201-202. London: Routledge, 2006.

Eaves, Morris, ed. The Cambridge Companion to William Blake. New York: Cambridge University Press, 2003.

Eliot, T. S. 1920. “Philip Massinger.” In Selected Essays, 205-220. London: Faber and Faber, 1951.

---. 1919. "Tradition and the Individual Talent.” In Selected Essays, 13-22. London: Faber and Faber, 1951.

Ezard, John. "Narnia Books Attacked as Racist and Sexist." The Guardian 3 June 2002. http://www.guardian.co.uk/uk/2002/jun/03/gender.hayfesti val2002. (accessed 14 February 2010).

"Faith and Fantasy." Encounter. ABC. Australia, 24 March 2002. http://www .abc.net.au/rn/relig/enc/stories/s510312.htm. (accessed 11 March 2010).

Firchow, Peter Edgerly. The End of Utopia: A Study of Aldous Huxley's Brave New World. London: Associated University Presses, 1984. 
Frietas, Donna and Jason King. Killing The Imposter God: Philip Pullman's Spiritual Imagination in His Dark Materials. San Francisco: Jossey-Bass, 2007.

Goodnow, Cecilia. "Young Adults See Reality Creeping Into Author's World of Faux Beauty." Seatle Pi 18 October 2007. http://www.seattlepi.com/life style/336024_uglies19.html. (accessed 1 July 2009).

Gray, William. "Pullman, Lewis, MacDonald, and the Anxiety of Influence." Mythlore Spring-Summer 2007. http://findarticles.com/p/articles/mi_m 0OON/is_3-4_25/ai_n27253238/. (accessed 5 August 2009).

Hatlen, Burton. 'Pullman's His Dark Materials, a Challenge to the Fantasies of J. R. R. Tolkein and C. S. Lewis, with an Epilogue on Pullman's NeoRomantic Reading of Paradise Lost." In His Dark Materials Illuminated: Critical Essays on Philip Pullman's Trilogy, edited by Millicent Lenz and Carole Scott, 75-94. Detroit: Wayne State University Press, 2005.

Huxley, Aldous. 1932. Brave New World. In Brave New World and Brave New World Revisited, 15-231. New York: Harper Perennial, 2005.

Johnson, Maureen. "Hot Sex and Horrific Parenting in His Dark Materials". In The World of the Golden Compass: The Otherworldly Ride Continues, edited by Scott Westerfeld, 43 -53. USA: BenBella Books, 2007.

Kleist, Heinrich von. 1810. "On the Marionette Theatre." Translated by Idris Parry. http://www.southerncrossreview.org/9/kleist.htm (accessed 21 October 2009).

Ladaga, Lili. "Philip Pullman Weaves Spell with His Dark Materials." CNN 10 November 2000. http://archives.cnn.com/2000/books/news/11/10/philip .pullman/. (accessed 23 November 2009).

Larbalestier, Justine, and Scott Westerfeld. "Interview”. 26 July 2006. http://slay ground.livejournal.com/113442.html. (accessed 23 November 2009).

Larbalestier, Justine, and Scott Westerfeld. "Teh Awesome Duo: Interview with Justine Larbalestier and Scott Westerfeld.” By John Scalzi. 2007. http://www.timetravelershow.com/cons/01\%20Teh\%Awesome\%Duo. mp3. (accessed 23 May 2009).

Leader, Zachary. Reading Blake’s Songs. London: Routledge \& Kegan Paul, 1981.

Lenz, Millicent, and Carole Scott, eds. His Dark Materials Illuminated: Critical Essays on Philip Pullman's Trilogy. Detroit: Wayne State University Press, 2005.

Lewis, C. S. 1966. "On Three Ways of Writing for Children.” In Of This and Other Worlds, edited by Walter Hooper, 56-70. London: Collins, 1982. 
---. 1956. The Last Battle. Reprint, London: HarperCollins, 2001.

---. 1950. The Lion, the Witch, and the Wardrobe. Reprint, London: HarperCollins, 2001.

---. 1955. The Magician's Nephew. Reprint, London: HarperCollins, 2001.

---. 22 January 1957. "Dear Martin.” In Letters to Children, 67. New York: Macmillan, 1985.

Meacham, Steve. "The Shed Where God Died." Sydney Morning Herald 13 December 2003. http://www.smh.com.au/articles/2003/12/12/1071 125644900.html. (accessed 16 September 2009).

Mellor, Anne Kostelanetz. Blake's Human Form Divine. Berkeley: University of California Press, 1974.

Milton, John. 1667. Paradise Lost. In The Poetical Works of John Milton, edited by Rev. H. C. Beeching, 173 - 448. Oxford: Oxford University Press, 1919.

Newlyn, Lucy. Paradise Lost and the Romantic Reader. Oxford: Clarendon Press, 1993.

Nodelman, Perry. The Hidden Adult: Defining Children's Literature. Baltimore, Md: John Hopkins University Press, 2008.

Paley, Morton D. The Continuing City: William Blake's Jerusalem. Oxford: Clarendon Press, 1983.

Peterfreund, Diana. "Ghost in the Machine." In The World of the Golden Compass: The Otherworldy Ride Continues, edited by Scott Westerfeld, 93-102. USA: BenBella Books, 2007.

"Pullman Attacks Narnia Film Plans." BBC 16 October 2005. http://news.bbc .co.uk/2 /hi/entertainment/4347226.stm. (accessed 23 November 2009).

Pullman, Philip. “An English Visonary.” New Statesman 18 December 2006. http://www.newstatesman.com/200612180060. (accessed 8 October 2009).

---. “An Interview with Philip Pullman.” More Intelligent Life. 3 December 2007. http://www.moreintelligentlife.com/node/697 (accessed 20 March 2010).

---. "Folio Society Edition of His Dark Materials Preface." http://www.philippullman.com/pages/content/index.asp?PageID=119. (accessed 13 February 2010).

---. 1995. Northern Lights. Reprint, London: Scholastic, 1998. 
---. 2000. The Amber Spyglass. Reprint, London: Scholastic, 2001.

---. "The Darkside of Narnia." The Guardian 1 October 1998.

http://www.crlamppost.org/darkside.htm. (accessed 4 August 2009).

---. “The Republic of Heaven.” Horn Book November 2001. http://www.hboo k.com/magazine.articles.2001/nov01_pullman.asp. (accessed 16 September 2009).

.--- 1997. The Subtle Knife. Reprint, London: Scholastic, 1998.

Roberts, Susan. “A Dark Agenda?” Surefish November 2002. http://www.sure fish.co.uk/culture/features/pullman_interview.htm. (accessed 13 February 2010).

Rose, Margaret A. Parody//Meta-fiction: An Analysis of Parody as a Critical Mirror to the Writing and Reception of Fiction. London: Croom Helm, 1979.

Scally, Lisa. "Miraculous Bridges: Crossing Genre Boundaries via His Dark Materials." $\mathrm{PhD}$ thesis, Victoria University of Wellington, 2004.

Schleiermacher, Friedrich. Hermeneutics and Criticism and Other Writings. trans. Andrew Bowie. Cambridge: Cambridge University Press, 1998.

Schmidt, Lawrence K. Understanding Hermeneutics. Stocksfield: Acumen, 2006.

Schlock, Peter A. Romantic Satanism: Myth and the Historical Moment in Blake, Shelley, and Byron. New York: Palgrave Macmillan, 2003.

"Scott Westerfeld: New Kid in Town." Locus May 2006. http://www.locusmag. com/2006/Issues/05Westerfeld.html. (accessed 23 November 2009).

Shears, Jonathan. The Romantic Legacy of Paradise Lost: Reading Against the Grain. Surrey: Ashgate, 2009.

Squires, Claire. Philip Pullman, Master Storyteller: A Guide to the Worlds of His Dark Materials. New York: Continuum, 2006.

Thompson, Peter, and Glendyr Sacks, eds. The Cambridge Companion to Brecht. Cambridge: Cambridge University Press, 1994.

Townsend, John Rowe. "Paradise Reshaped." The Horn Book Magazine 78.4 (2002): 415-421. http://find.galegroup.com.vuw.ac.nz. (accessed 14 September 2009).

Truffaut, François, director. Fahrenheit 451. DVD. 1966. Universal City, California: Universal Studios, 2003. 
Tucker, Nicholas. Darkness Visible: Inside the World of Philip Pullman. Cambridge: Wizard Books, 2003.

Vizzini, Ned. "God is in the Stories: His Dark Materials vs. Narnia". In The World of the Golden Compass: The Otherworldly Ride Continues, edited by Scott Westerfeld, 143-153. USA: BenBella Books, 2007.

Westerfeld, Scott. Bogus to Bubbly: An Insider's Guide to the World of Uglies. New York: Simon Pulse, 2008.

---. Extras. New York: Simon Pulse, 2007.

---. "EXTRAS DAY!” 2 October 2007. http://scottwesterfeld.com/blog/2007/10/ex tras-day/. (accessed 13 March 2010).

---. "FAQ." http://www.scottwesterfeld.com/author/faq.htm. (accessed 20 March 2009).

---. "First Lines." 26 July 2008. http://www.scottwesterfeld.co $\mathrm{m} / \mathrm{blog} / \mathrm{p}=507$. (accessed 4 December 2009).

---. "Inside the Golden Compass." 23 November 2007. http://scottwesterfeld.com/bl og/2007/11/inside-the-golden-compass/. (accessed 13 March 2010).

---. Leviathan. New York: Simon Pulse, 2009.

---, ed. Mind-Rain. Dallas: BenBella Books, 2009.

---. "Not Banned in Boston." 8 December 2007. http://www.scottwesterfeld.com/bl $\mathrm{og} / \mathrm{p}=348$. (accessed 17 February 2010).

---. Pretties. New York: Simon Pulse, 2005.

---. "Profile Page.” Amazon. http://www.amazon.com/gp/pdp/profile/AIUSWO SM0W9NB. (accessed 20 July 2009).

---. Specials. New York: Simon Pulse, 2006.

---. So Yesterday. New York: Razorbill, 2004.

---. "Stupid Perfect World”. In Love Is Hell, 55-112. New York: HarperCollins, 2008 .

---, ed. The World of the Golden Compass: The Otherworldly Ride Continues. USA: BenBella Books, 2007.

---. Uglies. New York: Simon Pulse, 2005. 
Wilkinson, Carole. "Pants on Fire: Truth, Lies, and Deception in The Golden Compass." In The World of the Golden Compass: The Otherworldly Ride Continues, edited by Scott Westerfeld, 5-14. USA: BenBella Books, 2007. 